Int. J. Dev. Biol. 58: 429-443 (2014)

doi: $10.1387 / \mathrm{ijdb} .140132 \mathrm{dw}$

\title{
Developmental biology of the leech Helobdella
}

\author{
DAVID A. WEISBLAT*,1 and DIAN-HAN KUO² \\ ${ }^{1}$ Dept. of Molecular and Cell Biology, University of California, Berkeley, USA and \\ ${ }^{2}$ Dept. of Life Science, National Taiwan University, Taiwan.
}

\begin{abstract}
Glossiphoniid leeches of the genus Helobdella provide experimentally tractable models for studies in evolutionary developmental biology (Evo-Devo). Here, after a brief rationale, we will summarize our current understanding of Helobdella development and highlight the near term prospects for future investigations, with respect to the issues of: D quadrant specification; the transition from spiral to bilaterally symmetric cleavage; segmentation, and the connections between segmental and non-segmental tissues; modifications of BMP signaling in dorsoventral patterning and the O-P equivalence group; germ line specification and genome rearrangements. The goal of this contribution is to serve as a summary of, and guide to, published work.
\end{abstract}

KEY WORDS: embryonic patterning, Helobdella, leech, Lophotrochozoa, spiralian

\section{Introduction}

Two types of questions motivate the field of Evo-Devo. First, what developmental mechanisms governed embryogenesis in now-extinct metazoan species at various nodes of the phylogenetic tree? And second, what changes in development have occurred in the lineages leading from these ancient species to their modern descendants? These questions are based on the underlying truism that evolutionary changes in adult body plan arise from changes in the developmental processes by which the body plan arises. Interest in these questions is heightened by the discovery that animals ranging from cnidarians to vertebrates are remarkably similar in both the numbers and kinds of genes in their genomes. Thus, it appears that the dramatic differences in animal body plans arise from differences in how largely conserved sets of genes are regulated and deployed during development.

Lacking a time machine to recover ancestral species for study, the accepted strategy for investigating these questions is to compare the development of extant species, interpreting similarities and differences in light of the phylogenetic tree by which they arose. Similarities are candidates for features present in the ancestor of the species under comparison, while differences reflect changes that have occurred in one or more of the lineages leading from the ancestor to the modern descendants.

This strategy brings up another challenge, that of reconstructing the phylogenetic tree required for interpreting the data emerging from developmental comparisons among species. The problem is particularly acute for the large numbers of soft-bodied species and the expanses of evolutionary history for which no good fossil record is available. Traditional phylogenetic methods of grouping animals based on similarities and differences in morphology or embryology build on assumptions about the nature of the evolutionary changes we seek to elucidate, which introduces an inherently circular logic to the Evo-Devo undertaking. This problem is avoided by using molecular sequence comparisons to construct phylogenies without references to morphological or developmental features. Such analyses have led to the recognition of three superphyla of bilaterally symmetric animals, Deuterostomia, Ecdysozoa and Lophotrochozoa, which emerged before the Cambrian era. Of these, Lophotrochozoa is at once the largest in terms of recognized phyla and also the least well represented in terms of current experimental systems. While the precise phylogenetic structure and characteristics of this group remain in flux, Lophotrochozoa appears to have spiral cleavage as an ancestral feature (Giribet, 2008; Struck, 2014). Thus, in comparing the mechanisms by which, for example, bilateral mesoderm arises from the $4 \mathrm{~d}$ micromere in annelids, flatworms, mollusks and their allies, we are peering back through the mists arising from roughly 600 million years of evolutionary tinkering at exactly homologous cells and cell lineages.

Traditionally the phylum Annelida (segmented worms) has been divided into three classes, polychaetes, oligochaetes and leeches, but it is now recognized that except for the leeches, these divisions do not correspond to distinct monophyletic entities. The leech clade arises from within the oligochaetes, and the

Abbreviations used in this paper: $\mathrm{BMP}$, bone morphogenetic protein; DV, dorsoventral; G1, gap phase-1 of cell cycle; G2, gap phase-2 of cell cycle; MAPK, mitogen-activated protein kinase; SYC, syncytial yolk cell; TGF $\beta$, transforming growth factor beta.

\footnotetext{
*Address correspondence to: David A. Weisblat. Dept. of Molecular \& Cell Biology, 385 LSA, University of California, Berkeley, CA 94720-3200, USA. Tel: +1-510-642-8309 . Fax: +1-510-643-6791. E-mail: weisblat@ berkeley.edu - web: http://mcb.berkeley.edu/labs/weisblat
}

Accepted: 18 September 2014.

ISSN: Online 1696-3547, Print 0214-6282 


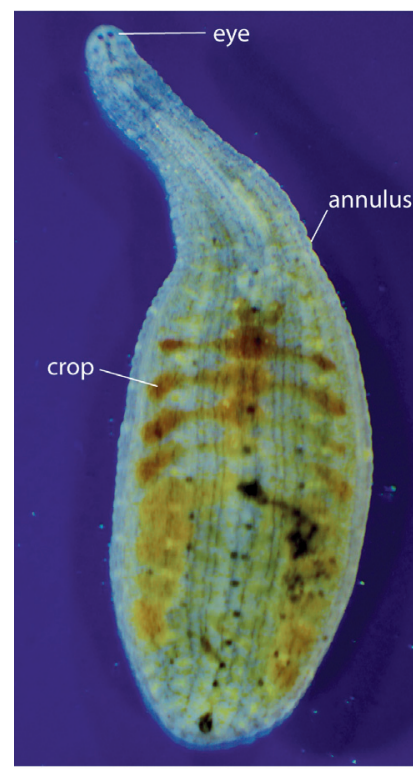

Dorsal view

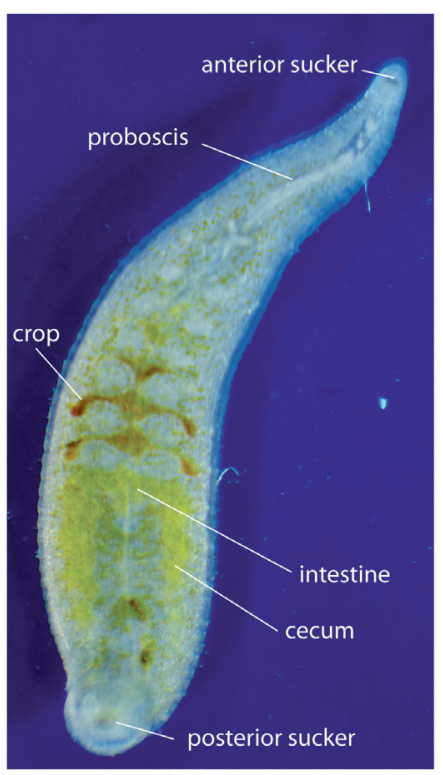

Ventral view

oligochaetes and leeches together form a clade designated as Clitellata, which arises from within the polychaetes (McHugh, 2000; Siddall, 2001; Struck et al., 2011). Some unsegmented taxa previously regarded as distinct phyla also arise from within the polychaetes (McHugh, 2000). This finding provides further evidence of evolutionary plasticity of the body plan, and of the problems arising from traditional phylogenetic methods.

\section{Overview of Helobdella development}

Compared to polychaetes and oligochaetes, leeches are characterized by an absence of segmental bristles (chaetae), and by modification of their anterior and posterior ends to form suckers, correlated with a fixed number of body segments. (Fig. 1). Neurobiologists have established a simplified nomenclature for leech segments based on the gross anatomy of the segmental ganglia (there is also an anterior-dorsal ganglion that is not segmental in origin (Weisblat et al., 1984; Shankland

Fig. 2. Segmental mesoderm and ectoderm in Helobdella arise by determinate cell lineages from a posterior growth zone composed of five bilateral pairs of lineage-restricted stem cells (M, N, O/P and $\mathbf{Q}$ teloblasts). For clarity, only the mesoderm is shown on the left and only the ectoderm is shown on the right; gastrulation movements are omitted. The time line (left) shows the approximate clonal age (hours) of the blast cell clones. Individual blast cell clones (for the $M$ and O/P teloblasts) or pairs of clones (for the $N$ and $Q$ teloblasts) are highlighted by colors at three time points: 1) as undivided cells; 2) at their first mitosis $12 \mathrm{hrs}$ for $\mathrm{m}$ blast cells, 40-48 hrs for the ectodermal blast cells; 3) as sets of definitive progeny (>150 hrs). Note that for the $M, O$ and $P$ lineages the clone of a single blast cell makes one segment's worth of definitive progeny, although the individual clones are distributed across more than one segment in each case; thus, a typical $m$ blast cell contributes muscles to one segment, a nephridium to the next posterior segment, and a few neurons to the segment after that. For both the N (ventral) and $Q$ (dorsal) ectodermal lineages, alternating blast cells undertake distinct patterns of division and differentiation and one clone of each type is required to make one segment's worth of progeny.

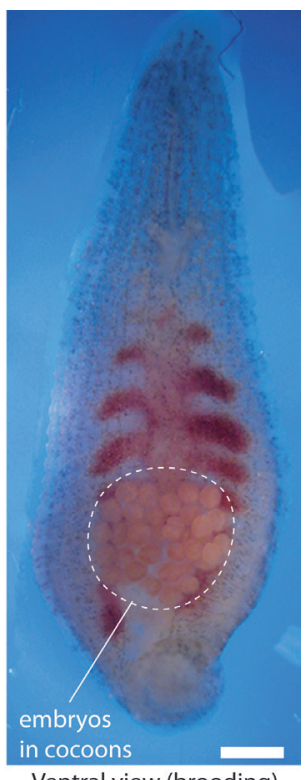

Fig. 1. Photographs of Helobdella austinensis adult (Kutschera et al., 2013). The trunk of Helobdella is annulated, however annulation is not prominent. Anterior and posterior suckers are located on the ventral side at the anterior and posterior ends. A pair of pigmented eyes can be found in the non-segmental prostomial region of the anterior end. Internal organs, such as the digestive tract, are visible through the body wall. Darker food material outlines the midgut (crop, intestine and ceca). Embryos are encased in transparent cocoons attached to the posterior ventral body wall of a brooding leech. Scale bar: $2 \mathrm{~mm}$.

and Savage, 1997): the rostral end of the animal comprises four segments, designated R1-R4, whose ganglia are fused to make the head brain; the midbody region comprises 21discrete segments designated M1-M21, each with its own segmental ganglion; the caudal region comprises 7 segments, designated C1-C7, whose ganglia are fused to make the tail brain.

Embryogenesis in clitellate annelids (leeches and oligochaetes) shows clear similarity at the cellular level. Segmental mesoderm and ectoderm arise in anteroposterior progression from a posterior growth zone composed of five bilateral pairs of lineage-restricted stem cells called teloblasts (Fig. 2). The teloblasts themselves arise from the zygote in a series of stereotyped cleavages, representing a derived version of spiral cleavage

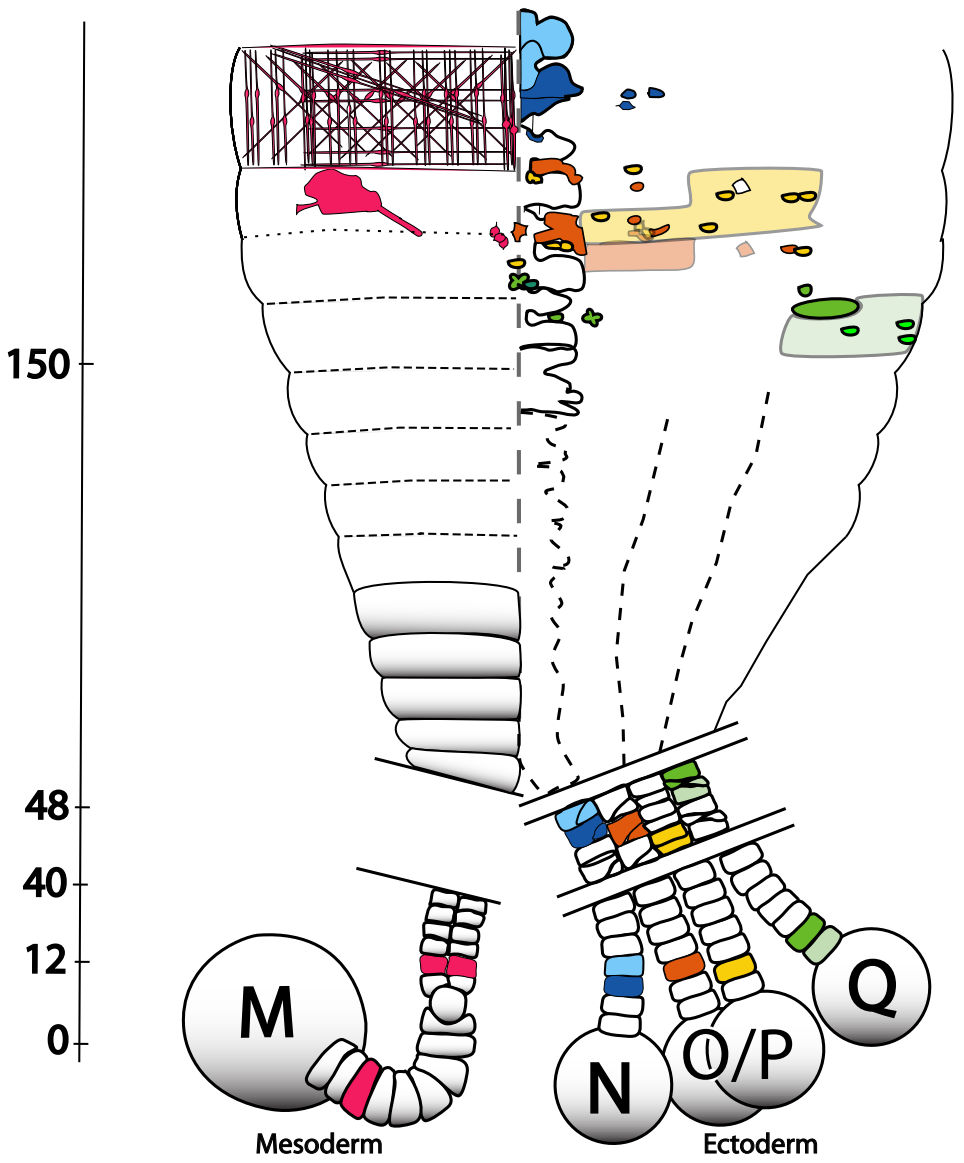


TABLE 1

\section{CORRESPONDENCE BETWEEN THE NAMES USED TO DENOTE KEY HELOBDELLA BLASTOMERES AND STANDARD SPIRALIAN NOMENCLATURE, AS REPRESENTED IN SANDIG AND DOHLE (1988)}

\begin{tabular}{cc} 
Helobdella & Standard Spiralian \\
\hline $\mathrm{D}^{\prime}$ & $1 \mathrm{D}$ \\
$\mathrm{d}^{\prime}$ & $1 \mathrm{~d}$ \\
$\mathrm{DM}$ & $2 \mathrm{D}$ \\
DNOPQ & $2 \mathrm{~d}$ \\
$\mathrm{DM}^{\prime}$ & $3 \mathrm{D}$ \\
$\mathrm{dm}^{\prime}$ & $3 \mathrm{~d}$ \\
$\mathrm{DM}^{\prime \prime}$ & $4 \mathrm{~d}$ \\
$\mathrm{dm}^{\prime \prime}$ & $4 \mathrm{D}$ \\
DNOPQ"' & $2 \mathrm{~d}^{222}$ \\
dnopq"' & $2 \mathrm{~d}^{221}$ \\
\hline
\end{tabular}

that is highly conserved among leeches, between leeches and oligochaetes, and to a lesser extent in the polychaete outgroups (Dohle, 1999). For glossiphoniid leeches, an embryonic staging system was devised, accompanied by a non-standard nomenclature based on knowledge of prospective cell fates in the embryo (Bissen and Weisblat, 1989; Fernández and Stent, 1980; Weisblat and Huang, 2001; Huang et al., 2002; Table 1; Fig. 3). While this nomenclature appears at first to complicate comparisons with spiralian taxa outside Clitellata, it also enables the naming of cells without making controversial assumptions about which cells are homologous across widely separated species, in which cell divisions have been described with varying degrees of precision.

Hermaphroditism and unequal cleavage are ancestral traits for the clitellates. So far as is known, Helobdella is unique for the clade in that several species are capable of self-fertilization as well as cross-fertilization (Wedeen et al., 1990; Tan et al., 2004; Cho et al., 2014; DAW unpublished observations). Next to the asexual reproduction by adult fission seen in some flatworms and oligochaetes, self-fertilization provides the ultimate ability for recovering from population bottlenecks associated with relatively ephemeral freshwater habitats. In addition, cross-fertilization in glossiphoniid leeches is achieved by random implantation of a spermatophore in the body wall, which can be traumatic and even lethal for a small individual (DAW personal observation). We speculate that this risk associated with cross-fertilization would tend to balance the genetic disadvantages associated with self-fertilization in Helobdella species, whose individuals are small (1-2 cm in length).

\section{Fertilization and cleavage}

As for all leeches, fertilization in Helobdella is internal and initiates meiosis of the egg nucleus. The fertilized eggs ( $\sim 400$ microns diameter) arrest at metaphase of meiosis I until they are deposited in cocoons, from which they are easily removed and cultured in dilute salt solutions. Thus, while in vitro fertilization has yet to be achieved for Helobdella, developmental events beginning with polar body formation are readily accessible. In clitellates such as Helobdella, unequal cleavage entails the formation of yolk-deficient, mRNA- and organelle-rich domains of cytoplasm (teloplasm) at the animal and vegetal poles of the zygote. Two unequal, roughly meridional cleavages segregate teloplasm to macromere D (Figs. $3,4)$. Then the first, highly unequal, dextrorotatory spiral cleavage generates an animal pole quartet of micromeres (a'- $d$ ') and a vegetal quartet of macromeres (A'-D'), corresponding to 1a-1d and $1 A-1 D$ in standard spiralian nomenclature. The $A, B$ and $C$ quadrants each form three micromeres (a'-a"', b'-b'", c'-c"') after which macromeres A"', B"' and C'" cease dividing. Curiously, the
Fig. 3. Schematic depicting key events during cleavage (stages 1-7). Animal pole views, micromeres are not labeled. Fertilization is internal, but the embryos arrest in female meiosis until zygote deposition. During stage (1), after formation of the two polar bodies (tiny circles), cytoplasmic rearrangements form yolk-deficient domains of cytoplasm (teloplasm) at the animal and vegetal poles. Animal pole teloplasm originates as a concentric ring (gray circle), which closes at the animal pole as the female pronucleus shifts to the center of the zygote after meiosis. In

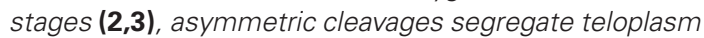
(gray circles) to the D macromere. Stage (4a) is marked by the formation of the first micromere quartet. In stage (4b), macromere $D^{\prime}$ undergoes an obliquely horizontal cleavage to form cells DNOPQ and DM $(2 d$ and $2 D$ in standard nomenclature). After forming additional micromeres, stage (4c) is marked by the division of cell DM" into left and right $M$ teloblasts. Only the left $M$ teloblast is visible from the animal pole. After forming yet more micromeres, stage (5) marks the division of cell DNOPQ"' into left and right NOPQ cells (teloplasm is still present, but not shown here). More micromeres arise, then the NOPQ" cells form N teloblasts and OPQ proteloblasts in stage (6a). After yet more micromeres are formed, stage (6b) is marked by the formation of OP proteloblasts and $Q$ teloblasts from OPQ" cells. Finally, after producing four op blast cells, the OP proteloblasts divide equally to form pairs of O/P teloblasts, which marks the beginning of stage (7).

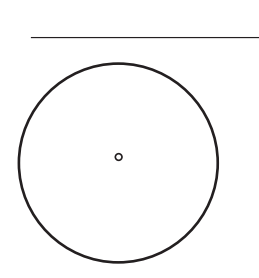

stage 1
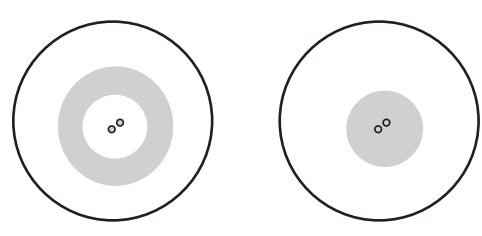

stage $4 b$
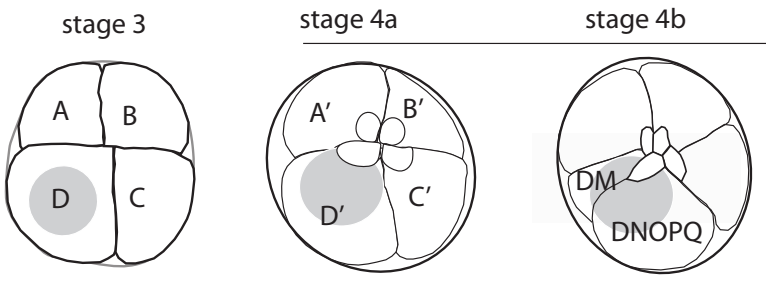

stage 3
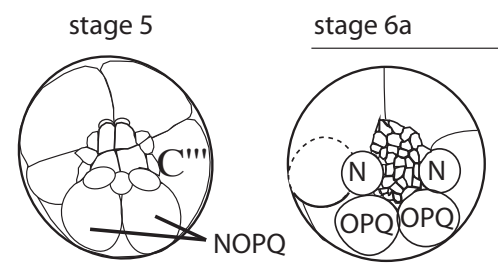

stage $6 \mathrm{~b}$
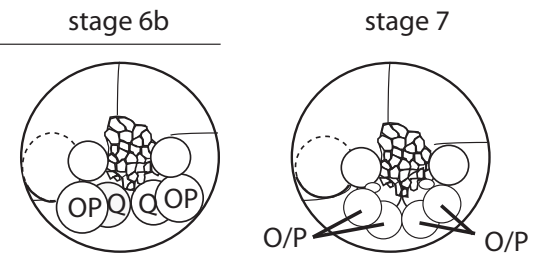
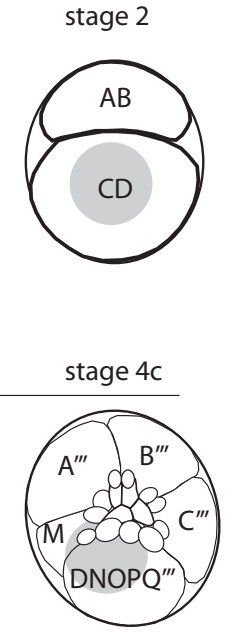
B quadrant in glossiphoniid leeches has either lost its spiral cleavages or makes them in anti-phase to those in the other quadrants (Sandig and Dohle, 1988; Bissen and Weisblat, 1989). The three macromeres contribute to midgut endoderm as will be described in more detail later. First quartet micromeres contribute the nonsegmental, dorsal anterior ganglion of the nervous system and to the epidermis of a provisional body wall that forms during epiboly (Weisblat et al., 1980; Weisblat et al., 1984). The secondary and tertiary micromere trios contribute progeny to other non-segmental fates (Smith and Weisblat, 1994; Huang et al., 2002).

Cell divisions are asynchronous and vary in duration in a cellspecific manner. Cycle times during cleavage vary from one to several hours in duration; equivalent divisions are faster in the $D$ quadrant lineage. G1 phase is absent during cleavage and most of the variation in cell cycle duration results from changes in the duration of the G2 phase (Bissen and Weisblat, 1989).

Macromere D' undergoes an idiosyncratic series of modified spiral cleavages, starting with an obliquely equatorial fourth cleavage to form ectodermal and mesodermal precursors of roughly equal size, cells DNOPQ (2d) at the animal pole and DM (2D) at the vegetal pole (Figs. 3, 4). Further divisions lead to formation of the five bilateral pairs of teloblasts and 15 much smaller cells, which are designated as micromeres by virtue of their small size rather than the orientation of the cleavage by which they arise (Figs. 3, 4). These micromeres also contribute to various non-segmental tissues in a lineage-specific manner (Smith and Weisblat, 1994; Huang et al., 2002).

A single pair of mesodermal $(\mathrm{M})$ teloblasts arises at seventh cleavage by the bilateral division of a large vegetal blastomere designated DM"'(Figs. 3, 4). This lineage is presumably homologous to micromere $4 \mathrm{~d}$ in standard spiralian nomenclature, but appears more similar to macromere 4D in size and position. One might ask whether this difference reflects a reassignment of the mesodermal fate from $4 d$ to $4 \mathrm{D}$, or rather a change in the relative sizes and positions of $4 d$ and $4 \mathrm{D}$. In any case, this modification to spiral cleavage further warrants the use of non-standard nomenclature
Fig. 4. Summary of early lineages in the Helobdella embryo. In general, large cells are designated with capital letters and small cells are designated with lower case letters. Teloblasts are highlighted by shaded circles. Cell DNOPQ is the homolog of micromere $2 d$ in standard spiralian nomenclature and DM" is the presumptive homolog of micromere $4 d$. Cells we designate as micromeres are highlighted by colored rectangles, and cells that give rise to equivalent or bilaterally symmetric clones in $\mathrm{H}$. robusta (Huang et al., 2002) are designated by the same color (i.e., $a^{\prime}$ and $b^{\prime}, c^{\prime}$ and $d^{\prime}, c^{\prime \prime \prime}$ and $d m^{\prime}, d n o p q^{\prime}$ and dnopq", left and right nopq' and nopq", left and right $o p q$, left and right opq", left and right $\left.n^{\prime}\right)$. Segmental founder cells for each lineage are indicated by colored type. Note that each $M$ and $N$ teloblast generates cells (em1-em6 and micromere n', respectively) that do not contribute segmental progeny (Zhang and Weisblat, 2005; Gline et al., 2011), while the OP proteloblast makes op blast cells that do contribute segmental progeny (Kuo and Shankland, 2004a). Thus the cells contributing to the anteriormost segments from each of the five lineages arise at about the same time. Endoderm arises from cellularization of a syncytial yolk cell (SYC), which forms by the stepwise fusion of macromeres, teloblasts and supernumerary blast cells (Liu et al., 1998; Isaksen et al., 1999; Desjeux and Price, 1999). See text for details. Abbreviations: pb, polar body; SYC, syncytial yolk cell.

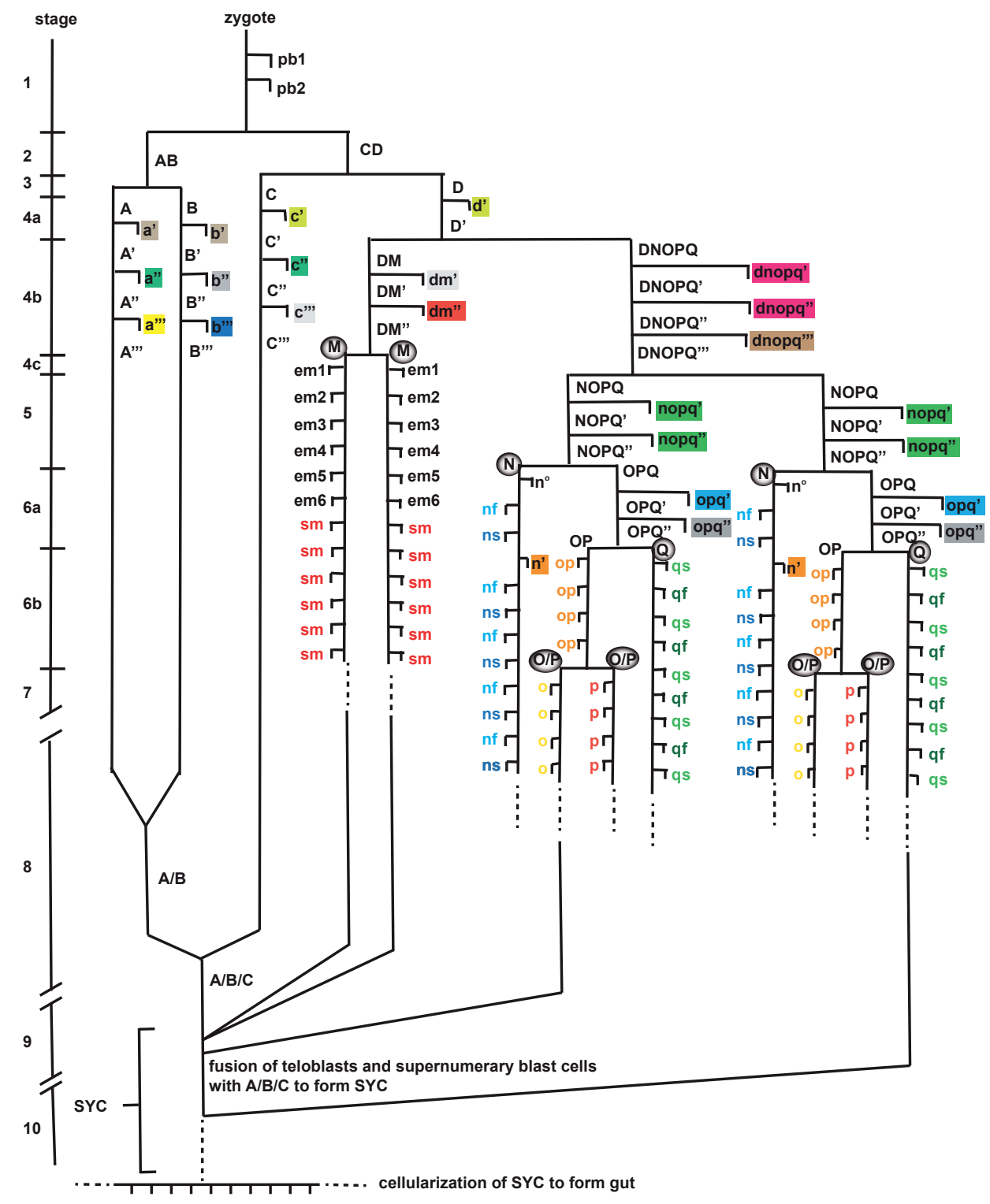


Fig. 5. Formation of germinal bandlets and germinal bands. (A) Schematic depicting a late stage 7 embryo (animal pole view), showing the relationship of teloblasts, blast cells, bandlets and germinal bands. The left M, N and O/P teloblasts are labeled. Not all teloblasts are visible. The micromere-derived epithelium that covers the germinal bands and the dorsal territory between them is indicated by an irregular meshwork. (B) A more detailed view of the left germinal band, showing the initial mitotic patterns within the $m$ and $n$ bandlets. Colors indicate the phase of the cell cycle: green $=S$ phase $;$ purple $=G 2$ phase $;$ red $=M$ phase; yellow $=G 1$ phase. (C) Details regarding the formation of the $O$ and $P$ lineages. In stage $6 b$, the OP teloblast precursor makes four op blast cells, which contribute $O$ and P pattern elements to segments R1-R4, comprising the head of the leech and then divides symmetrically to form the ipsilateral pair of bipotent O/P teloblasts.

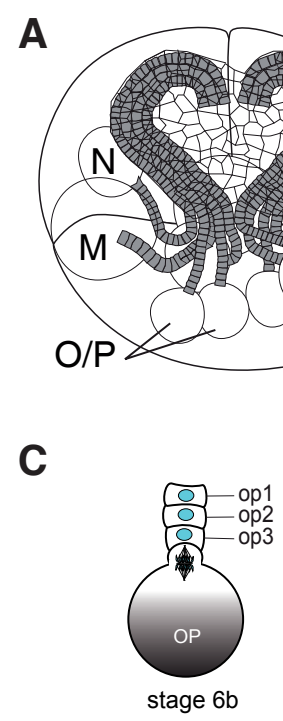

B
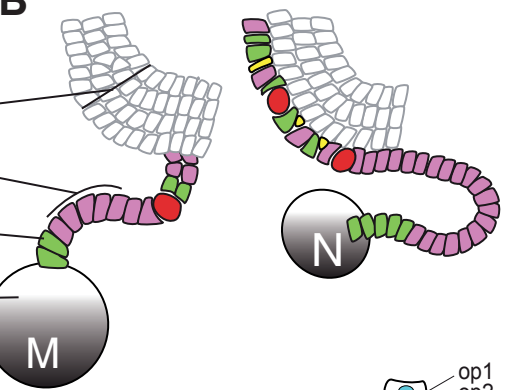

to refer to blastomeres in leech embryo. Four pairs of teloblasts arising from DNOPQ are the precursors of segmental ectoderm, and are designated as $\mathrm{N}, \mathrm{O}, \mathrm{P}$ and $\mathrm{Q}$ (or $\mathrm{N}, \mathrm{O} / \mathrm{P}, \mathrm{O} / \mathrm{P}$ and $\mathrm{Q}$, as will be explained below; Fig. 4). Note that the $M, N, Q$ and $O / P$ teloblasts are born at different times, which raises questions as to how the production of segmental founder cells is coordinated among them (see below).

\section{Germinal band formation and epiboly}

Each teloblast undergoes relatively rapid $(\sim 1$ hour cell cycle), repeated, highly asymmetric divisions, giving rise to coherent columns (bandlets) of segmental founder cells (blast cells). Curiously, the OP proteloblasts each make four "op" blast cells before dividing equally to generate the ipsilateral pairs of O/P teloblasts (Figs. 3, 4).

The blast cell cycles are prolonged 10 to 40 -fold relative to those of the teloblasts, again by cell type-specific prolongation of the G2 phase (Bissen and Weisblat, 1989; Fig. 5). On each side of the embryo, the five columns of blast cells form parallel arrays (germinal bands), whose distal ends interact in a poorly understood manner with micromeres near the animal pole at the future anterior end of the embryo. Within each germinal band, the four ectodermal bandlets lie superficial to the single mesodermal ( $\mathrm{m}$ ) bandlet, as described in C.O. Whitman's pioneering $19^{\text {th }}$ century investigations and are designated as $n, o$, $p$ and $q$ respectively.

The space between the left and right germinal bands, corresponding to prospective dorsoanterior territory, is occupied in part by other micromere-derived cells. The germinal bands and the cells separating them are covered by a layer of squamous epithelial cells derived from specific micromeres. Collectively, this assemblage of cells is designated as the micromere cap.

As ongoing stem cell divisions of the teloblasts add more cells to the proximal, future posterior ends of the germinal bands, the germinal bands move ventrovegetally over the surface of the embryo (made up largely of the
A"'-C"' macromeres) and gradually coalesce in anteroposterior progression like a zipper, with the $\mathrm{n}$ bandlets in direct apposition along the prospective ventral midline of the embryo (Figs. 5, 6). Throughout their ventrovegetal migration, the germinal bands and the territory behind them remain covered by the micromere-derived epithelium, which thus spreads to eventually cover the entire embryo. This exemplifies the epithelial movement known as epiboly. The micromere-derived epithelium, reinforced at its basal surface by contractile fibers of mesodermal origin, provides a provisional integument for the embryo.
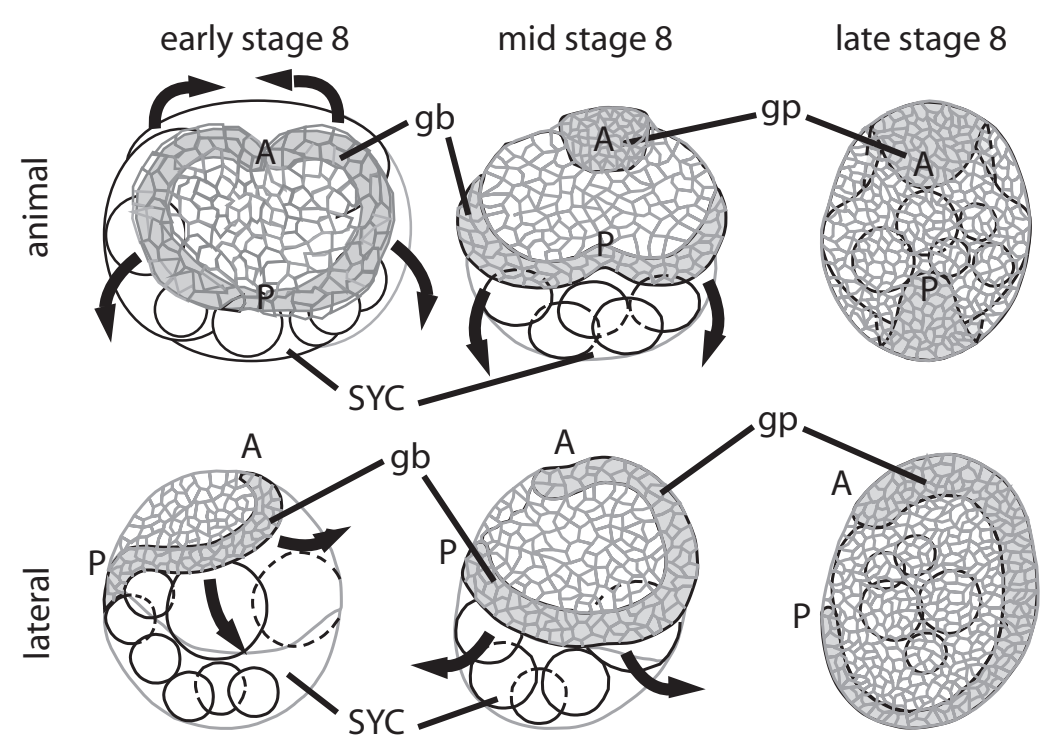

Fig. 6. Epiboly at early, mid and late stage 8 (L-to-R, respectively). Top row, animal pole views. Bottom row, lateral views with the forming germinal plate (ventral side) at right. Germinal bands and germinal plate are depicted in light gray. The micromerederived epithelium of the provisional integument is depicted as an irregular dark gray meshwork. The migrating germinal bands and epibolizing epithelium gradually encloses the syncytial yolk cell (SYC), which comprises the bulk of the embryo; teloblast remnants within the SYC are depicted by black circles. Arrows indicate the direction of germinal band movements and epibolic spreading of the provisional integument. Abbreviations: $A$, anterior; gb, germinal band; gp, germinal plate; $P$, posterior. 
Germinal band coalescence results in formation of a narrow, bilaterally symmetric sheet of cells called the germinal plate, from which segmental mesoderm and ectoderm will arise. During subsequent stages, as cells proliferate within the germinal plate, it expands dorsolaterally, displacing the provisional integument. In parallel, the yolk is elongated as the midgut forms. Eventually, the edges of the germinal plate meet at the dorsal midline, closing the body tube of the developing leech (Fig. 7).

Normally, the developing embryos hatch from their fertilization envelopes and from their cocoons and yet remain attached to the ventral body wall of the parent until their yolk is exhausted and development is complete. Curiously, the hatching occurs well before either the anterior or posterior suckers are functional. A subtle prominence at the anterior end of the germinal plate appears to secrete both the hatching enzyme (because that is the site over which the fertilization membrane is first opened) and also adhesive substances by which the embryos stick to the ventral body wall of the parent. Later, the posterior suckers mature and the embryos use those to fix themselves to the parental body wall. This occurs before the anterior sucker has developed, so during this time, the embryos are dangling from the parental body wall like Medusa's serpentine hair.

\section{Lineage-driven segmentation of mesoderm and ectoderm}

The first applications of microinjected marker substances as embryonic cell lineage tracers (Weisblat et al., 1978; Weisblat et al., 1980) were in the Helobdella embryo, and were undertaken to test Whitman's proposal that the $\mathrm{N}$ teloblasts and $\mathrm{n}$ bandlets in glossiphoniid leeches are the exclusive progenitors of the neurons of the ventral nerve cord. The situation proved more complicated than Whitman had proposed-each of the five bandlets contributes a spatially stereotyped pattern comprising diverse cell types to each segment (Fig. 2). The specific sets of segmentally iterated cells arising from the five teloblasts are designated the $\mathrm{M}, \mathrm{N}, \mathrm{O}, \mathrm{P}$ and
Q kinship groups, respectively; thus, for mesoderm and ectoderm, the left and right halves of each segment comprise the summation of one each of the five kinship groups (Fig. 2).

In addition to a few peripheral neurons and epidermal cells in ventral territory, the $\mathrm{N}$ kinship group includes most of the neurons for the ganglia of the ventral nerve cord, which are individually identifiable in glossiphoniid leeches as in the medicinal leeches of the genus Hirudo (Kramer and Weisblat, 1985; Muller et al., 1981). In contrast, the $Q$ kinship groups include primarily epidermal cells and peripheral neurons in dorsal territory, while the $\mathrm{O}$ and $P$ kinship groups comprise distinct mixed sets of epidermal cells and peripheral neurons in ventrolateral and dorsolateral territory, respectively (Fig. 2). However, the $O, P$ and $Q$ lineages also contribute specific sets of ganglionic neurons and glia as well, thanks to the migration of specific precursor cells (Torrence and Stuart, 1986; Braun and Stent, 1989a; Braun and Stent, 1989b).

The occurrence of these lineage-restricted stem cells contributing spatially stereotyped sets of segmental progeny is a prominent feature of leech development, and studies in clitellate embryos have revealed clearly homologous kinships groups (Storey, 1989; Goto et al., 1999a; Goto et al., 1999b; Nakamoto et al., 2000). But subsequent studies revealed further and even more intriguing details of what proved to be a highly lineage-driven segmentation process, including some features that so far appear to be unique to the clitellate annelids.

Segmentation in vertebrates and some arthropods (e.g., Drosophila) entails the imposition of boundaries upon fields of cells. Cell movements across the boundaries are restricted and cell division patterns within the territories delimited by boundaries are indeterminate (Fig. 8). In contrast to these boundary-driven processes, segmentation in Helobdella appears to result almost as an epiphenomenon of the highly stereotyped blast cell lineages (Weisblat and Shankland, 1985). The existence of the teloblastspecific kinship groups is strongly suggestive of tightly controlled blast cell lineages, and it was initially assumed that each kinship group would be the clone of a single blast cell from the correspond-

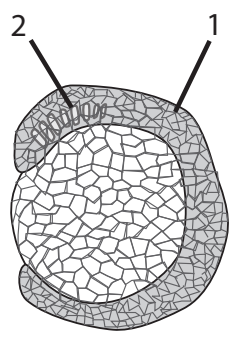

early stage 9 (lateral)

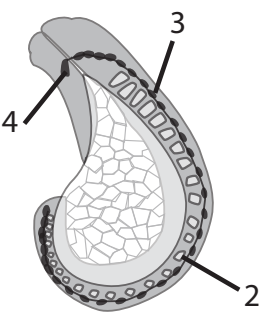

late stage 9 (lateral)

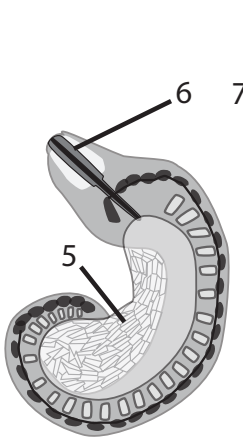

stage 10 (lateral)

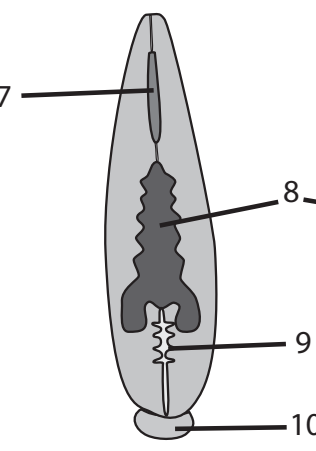

early stage 11 (dorsal)
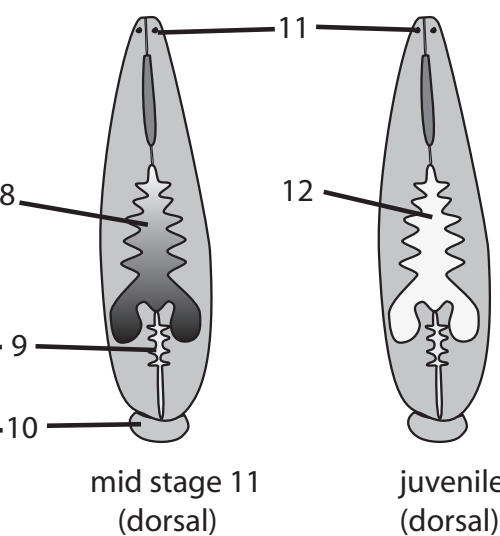

juvenile (dorsal)

Fig. 7. Late segmentation and organogenesis (stages 9-11). Anterior is up in all views; in lateral views, ventral is to right. Stage (9) begins when formation of the germinal plate (1) is complete; during stage 9, bilateral pairs of coelomic cavities (2) arise within the mesoderm in anterior to posterior progression. The ventral nerve cord (3) also becomes evident and is connected anteriorly by circumesophageal connective nerves to the dorsal ganglion (4). Stage (10) begins when the posteriormost coelom has formed; during stage 10, cell proliferation leads to lateral and dorsal expansion of the edges of the germinal plate, which gradually displaces the provisional epithelium (5) toward the dorsal midline. At the anterior end of the animal, the proboscis (6) differentiates in an everted position. Stage (11) begins when the lateral edges of the germinal plate have met all along the dorsal midline; stage 11 is marked by retraction of the proboscis (7) to its inverted position, elaboration of the crop ceca (8) and intestine (9), posterior sucker (10), and pigmented eye spots (11). Exhaustion of the yolk from within the crop (12) marks the transition from stage 11 to juvenile. 
ing lineage, but this proved not to be. Individual $\mathrm{m}$, $\mathrm{o}$ and $\mathrm{p}$ blast cell clones are as stereotyped as predicted but they extend across multiple segments - two in the case of the o and p blast cell clones and three in the case of the $\mathrm{m}$ blast cell clones (Fig. 2). Thus, each $\mathrm{M}, \mathrm{O}$ and $\mathrm{P}$ kinship group (i.e., the cells in one segment derived from a given teloblast) is formed by the longitudinal interdigitation of clones of two or more $\mathrm{m}$, o or p blast cells, respectively (Fig. 2).

The $N$ and $Q$ lineages exhibit an unexpected variant on the process of lineage-driven segmentation, in that two distinct types of blast cell clones in each of these lineages are required to generate a complement for cells for their respective kinship groups (Figs. 2, 4). This means that the bandlets of blast cells emanating from the $\mathrm{N}$ teloblasts (for example) come to comprise two distinct types of cell in exact alternation, which can be distinguished as nf and ns blast cells by differences in cell cycle duration, and also by differences in the orientation and degree of asymmetry of their initial mitoses (Zackson, 1984; Bissen and Weisblat, 1987; Bissen and Weisblat, 1989; Zhang and Weisblat, 2005) and subsequent mitotic patterns (Zhang and Weisblat, 2005). A key question is whether the nf and ns blast cells have distinct identities from birth, which implies some sort of flip-flop mechanism for cell fate assignment in the parent teloblast. Alternatively, initially equipotent blast cells could be patterned by signaling interactions operating on the bandlets. Ablation experiments suggest that the blast cells are committed to distinct $f$ and $s$ fates several hours before their first mitoses, and other studies suggest that there may be subtle differences in the cyokinetic processes by which nf and ns blast cells arise from the teloblast (Bissen and Weisblat, 1987), suggestive of a flip-flop mechanism. At the molecular level, it appears that the ns blast cells express higher levels of a cdc42 homolog than do nf cells (Zhang et al., 2009), but these differences were not evident in the cells most proximal to the teloblasts, so we regard this question as still open.

In either case, the fact that each $N$ and $Q$ teloblast makes two blast cells per segment indicates that they are a fundamentally different type of stem cell than the $\mathrm{M}$ and $\mathrm{O} / \mathrm{P}$ teloblasts, each of which makes just one blast cell per segment. Moreover, the fact that blast cell production rates are roughly the same for all teloblasts means that the $\mathrm{N}$ and $\mathrm{Q}$ teloblasts are producing "segmental equivalents" at half the rate of the $\mathrm{M}$ and $\mathrm{O} / \mathrm{P}$ teloblasts. One consequence of this disparity is that blast cells in the $n$ and $q$ bandlets must move past those in the $\mathrm{m}, \mathrm{o}$ and $\mathrm{p}$ bandlets within the germinal band, and the $\mathrm{m}, \mathrm{o}$ and $\mathrm{p}$ blast cell clones elongate relative to those of individual $n$ and $q$ blast cells, so that the blast cell clones destined to contribute to any particular segment eventually come into register (Weisblat and Shankland, 1985; Shankland, 1999). Another consequence is that the clones from different lineages contributing to any given segment are born at different times; moreover, the time difference between the birthdate of the $n$ and q versus $m, o$ and $p$ blast cells contributing to a given segment increases with more posterior segments (Lans et al., 1993). The different clones seem to proliferate and differentiate according to distinct lineage-dependent clocks rather than sharing a segment-specific clock. Even the segment-specific boundaries of Hox gene expression that are shared across the various teloblast lineages (Nardelli-Haefliger and Shankland, 1992) turn out to be established in a lineage-dependent manner (Nardelli-Haefliger et al., 1994).

Another set of open questions in leech segmentation is how the embryos count to large numbers with high precision. No natural variation in segment number has been observed for these animals. Thus, the posterior growth zone invariably generates exactly 32 segments in leeches (Euhirudinea). Sawyer (1986) reports that two deeply branching groups Branchiobdellida and Acanthobdellida make different, but also fixed, numbers of segments. And many oligochaete embryos exhibit indeterminate segmentation--new segments are added throughout life from a posterior growth zone that persists after the teloblasts are no longer evident. This difference in segmentation correlates roughly with the presence and absence of regenerative capacities in oligochaetes and leeches, respectively (Bely, 2006; Bely and Nyberg, 2010), and is certainly one of the greatest questions confronting those interested in annelid development. A possible hint at the answer emerges from the observations that teloblasts in Helobdella ultimately fuse with a syncytial yolk cell that is the precursor of the midgut endoderm (Fig. 4 and see below), whereas in the oligochaete Tubifex, no such fusions or syncytial yolk cells are reported (Shimizu, 1982a)

For Helobdella, counting out the segments is not controlled at the level of blast cell production--in addition to the 32 or 64 segmental founder cells, each teloblast makes a variable number
A

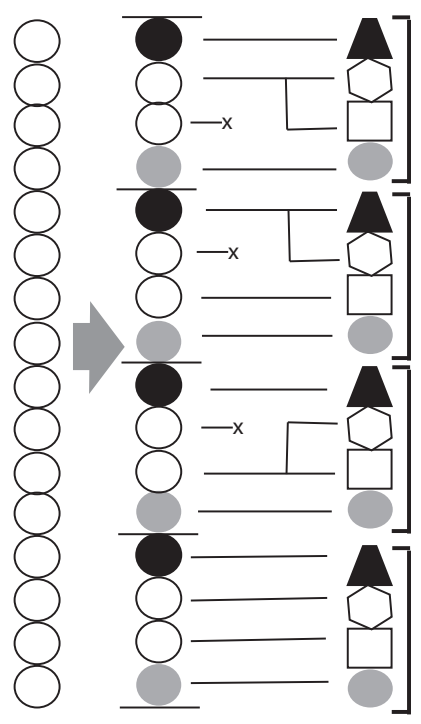

Fig. 8. Two modes of generating segmental patterning. (A) In boundary-driven segmentation, a critical step is the imposition of boundaries (indicated by arrow) on preexisting fields of cells (column of circles at left) to establish segment primordia (bracketed sets of figures in column at right). This may occur either sequentially as in vertebrates or simultaneously as in Drosophila. Cells do not normally cross the boundaries and cell division patterns (lines connecting middle column to right column, possibility of cell death represented by $x$ ) may vary among segment primordia, as long as the overall patterning process is conserved. (B) In lineage-driven segmentation, exemplified by clitellate annelids, longitudinally arrayed founder cells (left column) undergo highly determinate division patterns to generate spatially stereotyped clones of progeny (indicated by grey, dotted and black lines). In this case, repeating units (bracketed figures in column at right) will be generated even if adjacent clones interdigitate as shown. 
of supernumerary blast cells (Zackson, 1982; Shankland, 1984; Desjeux and Price, 1999; Fig. 4).

Despite various critiques and counter-examples (see Duboule, 2007), the generalization persists that clustered Hox genes are synonymous with a segmented body plan. Prior to the sequencing of the Helobdella genome, an extensive PCR and in situ hybridization survey of hox gene occurrence and expression in Helobdella gave results that were consistent with co-linearity between the domains of expression and the inferred architecture of the cluster (Kourakis et al., 1997). Recent whole genome sequencing gave some surprising new results, however. A mollusc-annelid complement of 11 hox genes has been inferred from the genome of a mollusc Lottia gigantea (this unsegmented animal contains all 11 genes in a single cluster) and a polychaete annelid Capitella teleta (where 11 orthologous genes are present in at most three clusters); in contrast, and notwithstanding its beautifully segmented body plan, Helobdella contains 19 hox genes: several of the canonical 11 genes have undergone one or more duplications; others appear to have been lost; and no scaffold contains more than 4 contiguous hox genes (Simakov et al., 2013). Clearly, revisiting the expression and regulation of the Helobdella hox genes should provide for informative tests of various aspects of the Hox dogma, such as co-linearity and posterior dominance.

\section{Segmentation and embryonic origins of endoderm}

In contrast to the condition in Drosophila and vertebrates, the leech midgut is also segmented; morphological segmentation of the midgut is presaged at the molecular level by iterated stripes of expression of the mRNA encoding homeodomain protein Lox10 (Nardelli-Haefliger and Shankland, 1993). Whitman (1878) proposed the $\mathrm{A}, \mathrm{B}$ and $\mathrm{C}$ quadrant macromeres as endodermal precursors, but here again the situation is more complicated. After the production of $D$ quadrant-derived precursors of segmental mesoderm and ectoderm is complete, the supernumerary blast cells and the teloblasts themselves are incorporated by cell fusion into a syncytial yolk cell (SYC), which has formed earlier in development by the stepwise fusion of macromeres A"', B"' and C"' during epiboly (Liu et al., 1998; Isaksen et al., 1999; Desjeux and Price, 1999; Gwendolen Y. Chang and DAW unpublished observations; Fig. 4); in other spiralians, macromere 4D is presumed to contribute to the midgut in parallel with the $\mathrm{A}, \mathrm{B}$ and $\mathrm{C}$ quadrant macromeres. In Helobdella, the midgut epithelium forms by cellularization of the SYC (Nardelli-Haefliger and Shankland, 1993); and proper patterning of endoderm depends on interactions with mesoderm (Wedeen and Shankland, 1997). Whether or not the original three macromere nuclei proliferate within the SYC prior to cellularization remains to be determined, but no additional nuclei were observed prior to teloblast and blast cell fusion (G.Y. Chang and D.A.W., unpublished observations).

More recently, results obtained from a detailed analysis of the mesodermal lineage raised further questions about the origins of endoderm in Helobdella (Gline et al., 2011). Using injections of plasmids and mRNA encoding a histone2B:GFP fusion protein as a nuclear lineage tracer, it was found that the first six blast cells produced by each $\mathrm{M}$ teloblast (now designated as em1 through em6) do not contribute canonical clones of segmental mesoderm, but rather distinct sets of progeny to a variety of other tissues. In particular, the em1 and em2 cells contribute dispersed clones of roughly 10-14 cells each in the region between the two germinal bands at early stage 8 . As segmentation and organogenesis proceed (stage 10-11) cells in the em1 and em2 clones are found widely distributed along the lumenal surface of the gastrointestinal tract from the proboscis through at least the posterior midgut, which seems at odds with the previously reported origins of endoderm from the SYC (Nardelli-Haefliger and Shankland, 1993). Whether the SYC and the em1/2 clones contribute equivalent or complementary sets of cells to the endoderm remains to be determined.

\section{Recent progress in Helobdella developmental biology}

\section{$D$ quadrant formation}

In equal cleaving spiralian embryos, the four quadrants of the embryo are initially equipotent, and the critical transition from fourfold radial to bilateral symmetry ( $D$ quadrant specification) occurs by inductive interactions some time after the 8-cell stage, depending on the species (Fig. 9). By contrast, unequal cleavage entails the

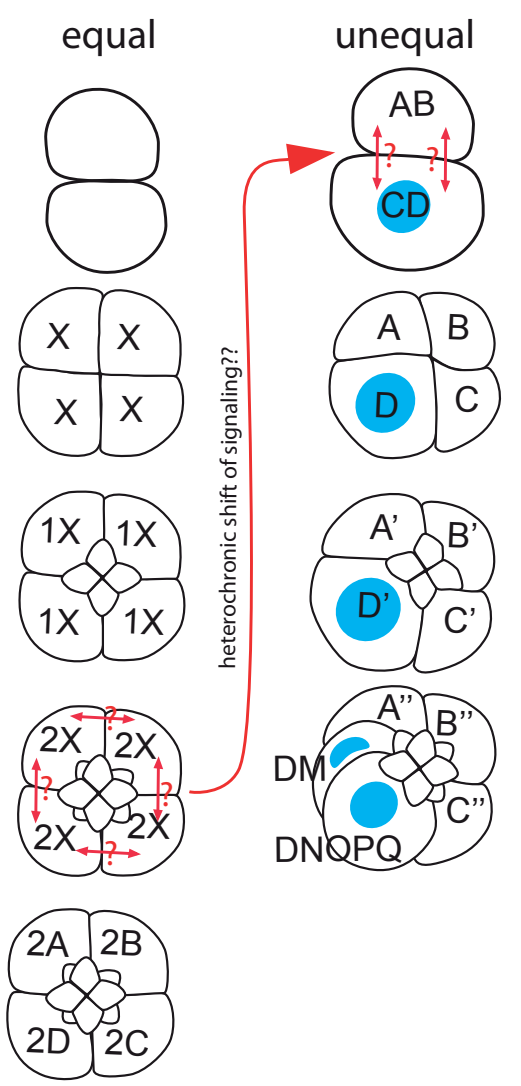

Fig. 9. Equal versus unequal cleavage. In what is proposed to be the ancestral mode of spiralian development (left), equal spiral cleavage leads to an early embryo with fourfold rotational symmetry $(X, 1 X, 2 X)$, a state that typically persists through at least fourth cleavage. Specification of the second embryonic axis (referred to as D quadrant specification in spiralian development) is presumed to involve the equivalent of lateral inhibition (red arrows at 12-cell stage), so that only one quadrant assumes the D fate. In unequal cleavers (right), D quadrant specification is achieved by unequal segregation of determinant factors (animal and vegetal pools of teloplasm in the case of the leech). We speculate that in the Helobdella embryo, this entails a heterochronic shift (acceleration) of ancestral signaling processes (red arrows at 2-cell stage). 
segregation of $D$ quadrant determinants in the first and second divisions, so that the embryo never passes through a state of true fourfold symmetry (Fig. 9). A landmark paper by Freeman and Lundelius (1992) made a compelling case for the assertion that equal cleavage was the ancestral condition for spiralian embryos. Whatever the condition of the ur-annelid, the ancestral condition for clitellate annelids is a version of unequal cleavage in which animal and vegetal domains of yolk-deficient cytoplasm (teloplasm) arise within the zygote following fertilization and meiosis. Teloplasm is segregated to the prospective $\mathrm{D}$ quadrant macromere by unequal first and second cleavages.

Notwithstanding the apparent homology of this process among clitellate annelids, the underlying cell biological mechanisms differ in several key points between Helobdella and the oligochaete Tubifex; these differences illustrate the evolutionary plasticity of developmental mechanisms in general and those regulating $D$ quadrant specification in particular. First, teloplasm formation is dependent on microtubule cytoskeleton in Helobdella but on the microfilament cytoskeleton in Tubifex (Astrow et al., 1989; Shimizu, 1982b). Second, the unequal cleavage of the Helobdella zygote is driven by a transient down-regulation of one centrosome during late metaphase (as judged by loss of gamma-tubulin immunoreactivity) and then the associated astral microtubules, in what was initially a symmetrical, bipolar mitotic apparatus; as in many embryos, the centrosome pair arises by duplication of the paternally derived centrosome (Ren and Weisblat, 2006). In Tubifex by contrast, the centrosome is maternally derived and fails to duplicate; thus the monastral spindle is highly asymmetric from the onset of mitosis (Ishii and Shimizu, 1995; Ishii and Shimizu, 1997). During second cleavage in Helobdella, both poles of a symmetric, biastral mitotic apparatus become closely associated with the cell cortex at the $A B-C D$ interface and is then either pulled or pushed toward the right side of the embryo in an actomyosin-dependent process (Lyons and Weisblat, 2009, Fig. 10). For the corresponding mitosis in Tubifex, the AB-CD interface is small compared to the mitotic apparatus; only one pole of the mitotic apparatus is associated with the cortex and the mitotic apparatus is markedly asymmetric (Takahashi and Shimizu, 1997)

Whatever the mechanisms involved, segregation of teloplasm to a single blastomere at the 4-cell stage is critical for $D$ quadrant specification in Helobdella. Any cell inheriting substantial amounts of teloplasm gains the capacity of executing the D quadrant-specific series of cleavages. It was originally assumed that animal and vegetal domains of teloplasm might contain specific ectodermal and mesodermal determinants, respectively, but this appears not to be the case: 1) vegetal teloplasm migrates to the animal pole and mixes with animal teloplasm prior to third cleavage in normal development (Holton et al., 1989);2) experiments combining cytoplasmic extrusion with centrifugation show that vegetal teloplasm can confer ectodermal fates, apparently subject to interaction with animal pole cortex (Nelson and Weisblat, 1992). Teloplasm is enriched in polyadenylated mRNAs (Holton et al., 1994), including maternally inherited transcripts such as the leech homologs of nanos, piwi, vasa and numerous other genes (Pilon and Weisblat, 1997; Kang et al., 2002; Cho et al., 2014). Consistent with the apparent equivalence of animal and vegetal domains of teloplasm, the transcripts examined so far have been observed in both the animal and vegetal domains. We also note that teloplasm is not a limiting factor in $D$ quadrant specification--in experimentally manipulated embryos, the presumptive $C$ and $D$ macromeres can both give rise to full complements of mesodermal and ectodermal teloblasts (Astrow et al., 1987).

The full molecular mechanism of $D$ quadrant determination is yet to be determined in detail for any spiralian species. Activation of a MAPK pathway appears to be a conserved feature across some, but not all species (Lambert and Nagy, 2001; Lambert and Nagy, 2003; Koop et al., 2007; Henry and Perry, 2008; Amiel et al., 2013); immunostaining for the phosphorylated MAPK reveals activation of a MAPK pathway in cells 3D or $4 d$ and treatment with inhibitors radializes the embryos. But MAPK pathways provide for intracellular signal transduction. A priori, some sort of cell-to-cell signaling must operate upstream or downstream of the MAPK cascade in equal cleavers, so that one and only one of the four quadrants assumes the $\mathrm{D}$ fate. It is tempting to postulate the involvement of canonical transmembrane receptor signaling pathways of the sort already known to mediate lateral inhibition and inductive signaling in numerous developmental contexts.

In Helobdella, activation of MAPK signaling is seen in the AB and CD cells during the 2-cell stage (Gonsalves and Weisblat, 2007), at least 4 cell cycles earlier than in the other spiralian systems where MAPK activation has been implicated in D quadrant specification (and inhibitor treatment does not radialize the Helobdella embryo).

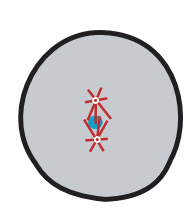

Zygote

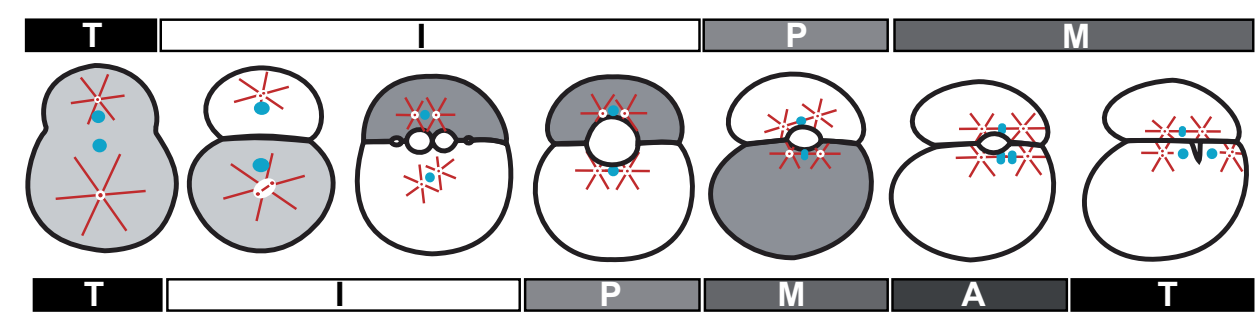

Fig. 10. Unequal cell division and dynamic gene expression during the unequal second cleavage in the Helobdella embryo (Lyons andWeisblat, 2009; Gonsalves and Weisblat, 2007). Bars above and below the diagrams indicate cell cycle progress of the prospective $A B$ and $C D$ nuclei (blue), respectively. In contrast to the situation at first cleavage (Ren and Weisblat, 2006), the mitotic apparatus (MA, microtubules in red) remains symmetric during second cleavage. The MA becomes closely apposed to the AB-CD interface, first contacting a transient blastocoel (white circle between the $A B$ and $C D$ cells) that arises during interphase and disappears by the onset of cytokinesis. The asymmetric division results from a rightward shift of the $M A$, mediated by actomyosin contractility. In parallel with the cytoskeletal processes, an intriguing pattern of dynamic gene expression during the 2-cell stage is exemplified by the changing distribution of notch transcripts. Maternal transcript (light gray shading in zygote and early CD cell) is selectively degraded in the early $A B$ cell. Then, zygotic transcripts accumulate transiently in the $A B$ cell while those in the CD cell are lost, followed by reappearance of notch in CD and disappearance from AB. Abbreviations: A, anaphase; I, interphase; $M$, metaphase; P, prophase; T, telophase. 
In Helobdella, MAPK activation alternates between the CD and AB cells during the 70 minutes of interphase with a set time course. Intriguingly, notch transcripts show a dynamic pattern of accumulation and degradation in the $A B$ and $C D$ cells that parallels that of MAPK activation (Fig. 10). The pattern of notch accumulation is associated with stabilization of maternal and early zygote notch transcripts and appears to be mediated by AU-rich elements (AREs) in the 3'-UTR; AREs confer MAPK-switchable mRNA (in)stability in mammalian systems (Chen and Shyu, 1995; Lasa et al., 2000).

Several wntgenes shows similarly dynamic patterns of transcript accumulation and degradation; and for Wnt7, immunostaining has shown that protein expression follows the in situ hybridization pattern (Huang et al., 2001; Cho et al., 2010). Moreover, the pattern of Wnt7 immunostaining exhibits features expected for a situation where lateral inhibition is operative-reducing the extent of contact between the $\mathrm{AB}$ and $\mathrm{CD}$ blastomeres (by separating the two cells at first cleavage, or simply by removing the physical constraint of the fertilization membrane prior to first cleavage) results in up-regulation of Wnt7 expression, with positive immunostaining in both cells. Many questions remain concerning this set of observations. Does MAPK signaling regulate the stability (or even the transcription) of the other genes showing dynamic patterns of transcript accumulation during the 2-cell stage? How many genes exhibit this pattern of dynamic early expression? More importantly, what is the embryological significance of this pattern? And perhaps most importantly, if early activation of MAPK signaling in Helobdella represents a heterochronic acceleration of events associated with stochastic specification of $D$ quadrant in an equally cleaving spiralian (Fig. 9), does it also mean that Wnt and/or Notch signaling is involved in the inductive interaction of $D$ quadrant specification in extant equal cleavers?

\section{Transition from spiral cleavage to bilaterality}

Spiral cleavage in early development is the defining characteristic of spiralian taxa. Micromere-producing spiral cleavage starts at the third cleavage and typically continues on for three more rounds of division. At the end of spiral cleavage, cells in the $2 \mathrm{~d}$ and $4 \mathrm{~d}$ lineages undergo equal divisions that yield left/right pairs of homologous ectodermal and mesodermal precursor cells--in leech it is cells 4d (DM" in Helobdella terminology), followed by the great-granddaughter of $2 \mathrm{~d}\left(2 \mathrm{~d}^{222}\right.$, or DNOPQ"' in Helobdella terminology) that undergo the bilateral divisions. It is generally accepted that these bilateral divisions are the first landmark of bilaterality in spiralian development. However, as is in many aspects of spiralian development, little is known how the transition from spiral cleavage to bilaterality occurs exactly. A recent finding in the leech has brought insight into molecular mechanism that regulates this spiral-to-bilateral transition (Schmerer et al., 2013).

It was shown that blocking Pax family transcription factor activity by expressing dominant negative constructs, as well as blocking transcription activity by inhibitor treatment, caused extra rounds of spiral cleavage in place of bilateral divisions of the ectodermal DNOPQ"' cell and the mesodermal DM" cell. This suggests that transcriptional activating activity of Pax is required for the transition from spiral cleavage to bilateral division. Furthermore, the key Pax protein involved in this process belongs to a subfamily that is unique to spiralian taxa, $\operatorname{Pax} \beta$ (Schmerer et al., 2009). This finding brings up the possibility that $\operatorname{Pax} \beta$ is evolutionarily and functionally linked to spiral cleavage, and this also brings up more questions about the regulation of spiral cleavage and cell lineage in the leech. For example, since these Pax genes were expressed as maternal transcripts, what are the factors that regulate the onset of their translation? What are the additional factors involved in the choice between the highly asymmetric, micromere-producing cell division and the more equal, teloblastogenic division? Answers to these questions may have important implications for the molecular mechanisms underlying the evolutionarily conserved spiralian developmental program.

\section{Connecting segmental and non-segmental tissues}

As mentioned above, the boundaries of the blast cell clones do not match the segmental boundaries in the $\mathrm{M}, \mathrm{O}$ and $\mathrm{P}$ lineages, as each blast cell clone spans two segments in $\mathrm{O}$ and $\mathrm{P}$ lineages and three in the $\mathrm{M}$ lineage (Fig. 2). Even the nf blast cell clone, which contributes cells primarily to the posterior portion of each segmental ganglion, has been shown to contribute a small number of cells to the anterior margin of the next ganglion back, before the ganglionic primordia separate (Shain et al., 1998). This disposition of blast cell clones raises a question concerning the anteriormost and the posteriormost segments--what becomes of the cells that would normally arise from or be contributed to the "missing" segments? Clearly, there must be some modification to the cell lineage patterns in these terminal segments and at the interface between segmental and non-segmental tissues.

Using high-resolution lineage tracing techniques, we have begun to understand how the connection between non-segmental tissue and the anterior segmental tissue is made. In the mesoderm, the M teloblast produces six 'em' blast cells before it starts to produce standard, purely segmental 'sm' blast cells. The first sm cell, sm1, contributes to segments $1-3$, sm2 to segments $2-4$, sm3 to segments 3-5, and so on. Interestingly, the two posteriormost em cells, em5 and em6, contribute to both non-segmental prostomium tissue and segments 1 and 2, and their segmental contribution appears to be homologous to the pattern elements arising from segmental sm blast cells in the more posterior segments (Gline et al., 2011; Fig. 4). In the $\mathrm{N}$ lineage, the first blast cell made by the $\mathrm{N}$ teloblast is termed $n^{0}$, as it makes a unique contribution that serves as a link between the segmental ganglia and prostomium tissue (Zhang and Weisblat, 2005); after making $\mathrm{n}^{0}$, the $\mathrm{N}$ teloblast sequentially generates one nf cell, one ns cell and then the n' micromere (which contributes squamous epithelium to the micromere cap (Smith and Weisblat, 1994; Smith et al., 1996) before resuming blast cell production. Thus, in the $\mathrm{M}$ and $\mathrm{N}$ lineages, some of the first few blast cells arising from the teloblast differ from the more posterior, standard segmental blast cells in that they make special contributions at the connection between the segmental tissues and the micromere-derived prostomium.

The $\mathrm{O}$ and $\mathrm{P}$ lineages follow yet another scenario. First of all, the OP proteloblast undergoes four rounds of teloblast-like asymmetric cell division, producing four 'op' blast cells before dividing equally to produce the ipsilateral pair of O/P teloblasts (Fig. 5). These four op blast cells do make segmental contributions, mainly to the four rostral segments (R1-R4); within these segments, the set of pattern elements arising from each op blast cell appears is largely identical to the sum of a set of o blast cell-derived pattern elements plus a set of $p$ blast cell-derived pattern elements. The clone of the first op blast cell, op ${ }_{1}$, straddles segments R1 and R2,

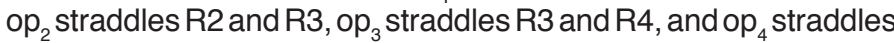


R4 and M1 (Shankland, 1987; Kuo and Shankland, 2004a). This leaves some otherwise segmentally iterated pattern elements absent from the R1 segment. It is not clear whether these pattern elements are completely missing in the R1 segment or are still present but come from the micromere lineage(s) instead. In any case, the OP lineage represents a different scheme to deal with the issue of serial homology in the anterior terminus of segmental tissue. A further consequence of these various modifications to the $\mathrm{M}$ and $\mathrm{N}$ lineages is that even though the teloblasts are born across a time span of 7 hours, the blast cells contributing to the first segment, R1, are born at about the same time, starting in stage 6 (Gline et al., 2011; Fig. 4).

\section{The O-P equivalence group and the evolutionary plasticity of BMP-mediated dorsoventral patterning systems}

In Drosophila and vertebrates, dorsoventral patterning entails formation of a morphogen gradient--a continuously graded activity of some signaling molecule across a field of cells; individual cells assume one of several fates as specified by various concentration thresholds for the signal. Cell lineage is usually of negligible importance for cell fate decisions within a morphogen field. In cell lineage-driven development by contrast, cell fate specification is typically coupled to mitosis; each fate decision is therefore binary, and cell-cell signaling is usually local and contact-dependent. Thus, by comparison with morphogen systems, the O-P equivalence group in leech provides a model for elucidating the evolution of dorsoventral patterning mechanisms.

Among the five bilateral pairs of teloblasts, the fates of the $\mathrm{M}$, $\mathrm{N}$ and $\mathrm{Q}$ teloblasts appear to be specified by cell autonomous processes, such that these cells are committed to their particular fates at birth. In contrast, the progenitor teloblasts of $O$ and $P$ lineages in Helobdellaare equivalent in their developmental potential, and thus they are designated 'O/P' to reflect their developmental plasticity. The primary blast cells in the ipsilateral $o$ and $p$ bandlets constitute a developmental equivalence group, in which fates of initially equipotent blast cells are specified by external positional cues.

Over theyears, cell ablation experiments have identified several cues that are involved in patterning the O-P equivalence group. First, ablation of the $\mathrm{P}$ lineage caused an $\mathrm{O}$-to-P fate change, but O lineage ablation did not induce a $\mathrm{P}$-to-O fate change (Shankland, 1984; Weisblat and Blair, 1984). This suggests that the $p$ bandlet normally prevents cells of the o bandlet from adopting the $\mathrm{P}$ fate. Second, ablation of the micromere-derived provisional integument that covers the germinal band induced an O-to-P fate change ( $\mathrm{Ho}$ and Weisblat, 1987), suggesting that this covering epithelium also prevents cells in the o bandlet from adopting the $\mathrm{P}$ fate. Finally, $\mathrm{Q}$ lineage ablation resulted in a $\mathrm{P}$-to-O fate change, indicating that cells of the $q$ bandlet induce the $P$ fate in adjacent $o / p$ blast cells (Huang and Weisblat, 1996).

While the O-P equivalence group is well studied at the cellular and embryological levels, we are only beginning to understand the underlying molecular mechanisms. It turns out that the O-P equivalence group is patterned by a complex network of BMP signaling (Kuo and Weisblat, 2011). Among the five genes encoding BMP-type TGF $\beta$ superfamily ligands in the leech genome, four are expressed in the germinal band. Hau-admp, Hau-bmp2/4a and Hau-bmp2/4b are broadly expressed in all bandlets. In contrast, Hau-bmp5-8 is specifically expressed in the q bandlet and is both necessary and sufficient for the specification of $P$ fate. This discovery was consistent with the previous $Q$ lineage ablation experiment, and suggests that the $q$ blast cells instruct the adjacent $\mathrm{o} / \mathrm{p}$ blast cells to adopt the $\mathrm{P}$ fate by producing Hau-BMP5-8. Intriguingly, Hau-BMP5-8 signaling in the O-P equivalence group appears to signal in a short-range, contact-dependent manner (Kuo and Weisblat, 2011).

Patterning of the O-P equivalence group also involves a BMP antagonist, gremlin. Models in which positional information is conveyed by opposing gradients of agonist and antagonist predict that the BMP antagonists would be expressed in ventral territory of the germinal band, i.e., the $\mathrm{n}$ or o bandlet. Surprisingly, however,
Fig. 11. A model for Helobdella O-P equivalence group patterning (based on data from Kuo and Weisblat, 2011). (A) In the absence of input from BMP5-8, homeostatic feedback between gremlin and the two BMP2/4s (Hau-BMP2/4a and Hau-BMP2/4b) maintains low levels of $B M P$ signaling activity along the DV axis. (B) A short-range BMP5-8 signaling from the dorsalmost q bandlet (1 in lowerpanel) elevates BMP signal activity specifically in the adjacent dorsolateral $p$ bandlet and not in the ventrolateral o bandlet. Elevated levels of BMP signaling in the $p$ bandlet up-regulate gremlin and genes that specify the P fate, such as Hau-six 1/2a (2 in lower panel). Up-regulation of gremlin in the $p$ bandlet further dampens BMP signal activity in the adjacent o bandlet to permit normal $O$ fate development $(3$ in lower panel), while signaling in the $p$ bandlet remains high due to the gremlin-insensitive BMP5-8 signal from the q bandlet.
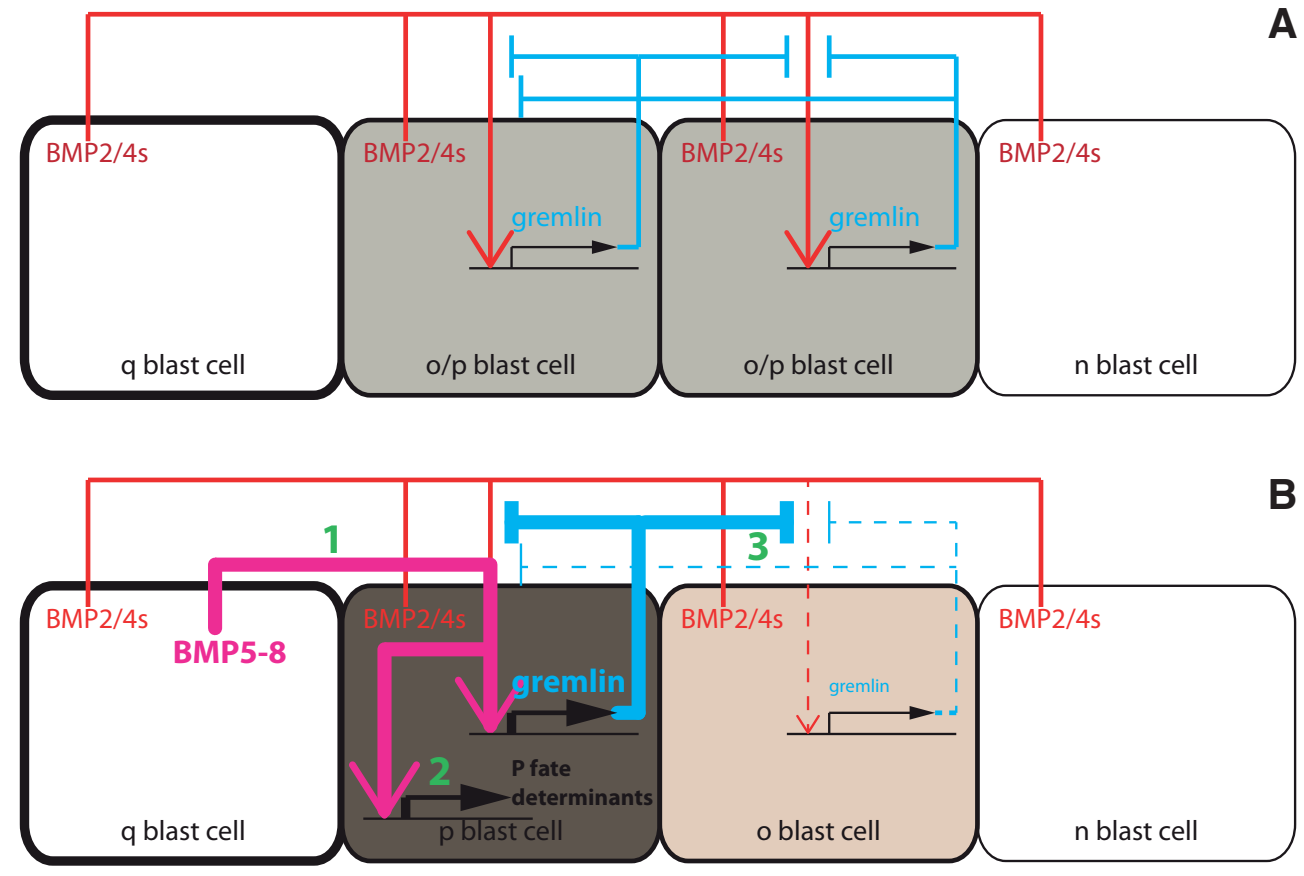
Hau-gremlin is expressed at highest level in the p blast cells, which happen to experience the highest level of BMP activity in the germinal band (Kuo and Weisblat, 2011). The resolution to this paradox is as follows. First, localized Hau-BMP5-8 up-regulates Hau-gremlin in the $p$ bandlet. Second, functional analysis indicated that the broadly expressed BMP2/4s, but not Hau-admp, are involved in O-P patterning, and Hau-gremlin only inhibits BMP2/4s, not BMP5-8. Together, these data suggest that a homeostatic feedback circuit may operate within the O-P equivalence group--BMP2/4 signaling up-regulates Hau-gremlin expression and Hau-gremlin inhibits the BMP2/4 signal. Superimposed on this, the gremlin-insensitive BMP5-8 from the $Q$ lineage drives the set point of BMP signaling activity higher in the $p$ bandlets; high BMP signaling in the $p$ bandlet then up-regulates gremlin expression; this then represses BMP2/4 signaling in the o bandlet, which is not affected by the short-range, contact-dependent BMP5-8 signal (Kuo and Weisblat, 2011; Fig. 11). Based on this model, the function of gremlin is to enhance the $\mathrm{O}-\mathrm{P}$ difference in BMP signaling activity initially induced by localized BMP5-8 signaling. Indeed, both Hau-gremlin knockdown and overexpression failed to induce a complete fate change, indicating an auxiliary, rather than dominant, role for gremlin in O-P patterning (Kuo and Weisblat, 2011).

Elucidating the function of Hau-gremlin helps to interpret the earlier $\mathrm{P}$ lineage ablation experiments, in which the $\mathrm{O}$ lineage transfates into $P$ after the original $P$ lineage is lost (Shankland, 1984; Weisblat and Blair, 1984). Two (non-exclusive) explanations for this result were as follows: (1) that the $p$ bandlet sends an inhibitory signal to repress $P$ fate in the o bandlet, and (2) that the physical presence of the $p$ bandlet serves as a steric block to prevent the o bandlet from contacting the $q$ bandlet (and thus the $\mathrm{P}$ fate inducing signal). Now, molecular data indicate that there is truth in both explanations. The normal $\mathrm{O}$ fate appears to require up-regulation of inhibitory gremlin in the $p$ bandlet. However, overexpression of gremlin alone is not sufficient for $O$ fate specification. Since BMP5-8 arising from the $q$ bandlet is not sensitive to gremlin, keeping the o blast cell from contacting the $q$ bandlet is another essential condition for normal $\mathrm{O}$ fate.

Thus, results of the functional analyses of BMP5-8 and gremlin provide cogent molecular explanations for the $Q$ ablation and $P$ ablation experiments. But, what about the ablation experiments involving the provisional integument? Since no transcripts of BMPspecific antagonists were detected in the provisional integument, we speculate that integumental repression of BMP signaling may be mediated by other multi-functional molecules such as extracellular matrix proteins (Zhu et al., 1999; Ohkawara et al., 2002; Takada et al., 2003; Wang et al., 2008; Olivares et al., 2009; Ramirez and Rifkin, 2009).

The axial polarity of BMP signaling in the O-P equivalence group is consistent with the evolutionarily conserved BMP axis, i.e., higher in the dorsal and lower in the ventral for all protostome taxa where BMP signaling is involved in dorsoventral patterning (De Robertis and Sasai, 1996). This suggests that the O-P patterning mechanism was derived from the dorsoventral BMP morphogen gradient. However, the deployment of BMP ligands and antagonists has been dramatically reorganized in the O-P equivalence group, presumably as an adaptation to the emergence of cell lineagedriven embryogenesis in the leech.

Further evidence that the O-P patterning mechanisms are evolutionarily flexible over a relatively short evolutionary span comes from the fact that $Q$ lineage ablation experiments performed on different clitellate species yielded different results (Arai et al., 2001; Kuo and Shankland, 2004b). Interestingly, BMP5-8 knockdown produces robust P-to-O fate change in Helobdella austinensis, in which a 'redundant' $\mathrm{m}$-derived $\mathrm{P}$ fate inducing signal was also identified by cell ablation experiments (Kuo and Shankland, 2004b). The discrepancy between the $Q$ ablation and BMP5-8 knockdown experiments could be explained if this $m$-derived signal only operates when the $q$ bandlet is physically removed from the germinal band. While it is not clear what molecular signal is responsible for this conditional, $\mathrm{m}$-derived, $\mathrm{P}$ fate-inducing signal, the $\mathrm{q}$ bandlet-derived BMP5-8 signal is nevertheless the primary $P$ fate inducing signal normally operating in $\mathrm{H}$. austinensis, just like in other Helobdella species. Interspecies difference in $Q$ ablation experiments, however, still reflects the yet-to-be-uncovered diversity in patterns and organizations of cell-cell interaction within the genus Helobdella.

\section{Germ line specification and genome rearrangements}

The embryonic origins of the germline in spiralians were enigmatic until relatively recently. The situation has improved considerably with the combination of lineage tracing and in situ hybridization techniques, building on the discovery that genes such as nanos, vasa, and piwi are broadly conserved markers of primordial germ cells (PGCs) in diverse taxa (Juliano et al., 2010). In Helobdella as in many other animals, it turns out that these markers are initially broadly expressed during early development, with expression becoming restricted to PGCs during stages 9-11. [As a simultaneous hermaphrodite, Helobdella species generate both male and female gametes, associated with one pair of ovaries in midbody segment 6 (M6) and 4-6 pairs of testisacs in segments M8 through M11 or M13, respectively]. An unexpected discovery was that the male and female PGCs initially express these markers differentially; nanos is expressed preferentially in the male PGCs at the same time that piwi and vasa are expressed preferentially in the female PGCs (Kang et al., 2002; Cho et al., 2014). A second conclusion of interest is that male and female PGCs arise from mesodermal blast cell of the segment with which they are associated. That is, the female PGCs arise in the $\mathrm{m}$ blast cell clone whose main contribution is to segment M6 (Cho et al., 2014), and presumptive male PGCs arise from $11 \mathrm{~m}$ blast cell clones contributing to segments M8-M18 (Kang et al., 2002). This latter result is discrepant with the fact that only with the final numbers of only 4-6 pairs of testisacs in Helobdella species in segments M8-M13. It was proposed that the 11 pairs of nanos-positive cells or cell clusters in the stage 11 embryo represent an ancestral set of pre-PGCs that is then pruned to the varying numbers of testisacs seen in modern leeches.

Taking into account the production of the various em blast cells before the $\mathrm{M}$ teloblasts even start producing segmental mesoderm (see section 3 above), the origins of PGCs from segmental mesoderm means that the germline does not segregate from somatic lineages in the Helobdella embryo until after more than 23 rounds of zygotic cell division have taken place (Fig. 12). This delayed segregation of germline and somatic lineages runs contrary to expectations of the preformation mode of germline specification. In the preformation mode, which offers the benefit of reducing the risk of chromosomal abnormalities that may arise during mitosis and reduce the quality of the gametes, PGCs are typically set aside at the earliest stages of development using mechanisms 
such as the formation of germ plasm. The relative contributions of inductive and cell autonomous fate decision processes to germline specification in Helobdella remain to be determined.

In any event, the fact that ipsilateral male and female PGCs

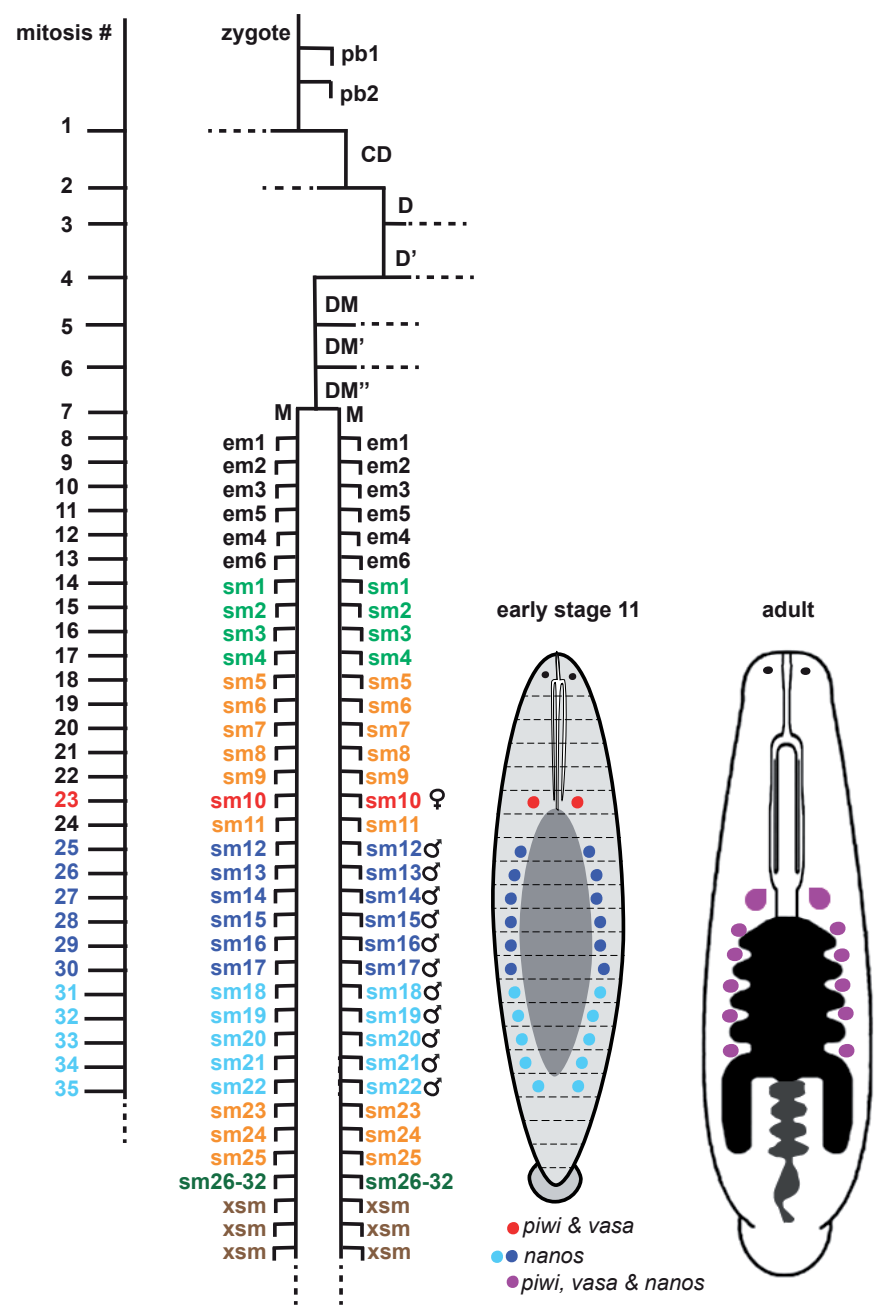

Fig. 12. Delayed segregation of germline precursors (PGCs) from the mesodermal (M) lineage in Helobdella. $M$ teloblasts arise at seventh cleavage, then initiate stem cell divisions: M progeny em 1-em6 contribute almost entirely to non-segmental tissues; sm1-sm4 (light green) contribute to rostral segments (R1-R4); sm5-sm25 orange, red, blue) contribute to midbody segments (M1-M21); sm26-sm32 (dark green) contribute to caudal segments (C1-C7); a small, variable numbers of supernumerary blast cells (xsm; brown) fuse with the SYC. Combined lineage tracing and in situ hybridization analyses showed that the female and male PGCs arise from the mesodermal blast cells that contribute somatic mesoderm to mid-body segments in which they are found, sm10 and sm12-sm22, respectively (Kang et al., 2002; Cho et al., 2014). Thus, ipsilateral male and female PGCs share a common lineage through 23 rounds of zygotic mitosis. Curiously, three widely conserved germ line markers are differentially expressed between the female and male PGCs in early stage 11, although these genes are co-expressed both in early development and in the adult gonads. Midbody mesodermal blast cells from which female PGCs arise (sm10) are indicated in red; those giving rise to presumptive male PGCs (sm12-sm22) are indicated in blue, but only some of these contribute to definitive testisacs (dark blue); orange indicates other midbody sm cells. share the same lineage for 23 rounds of mitosis increases the probability that any translocations that do occur will be shared between the male and female PGCs. In the case of a self-fertile hermaphrodite, this provides the opportunity to rescue a translocation in one gamete with a matching translocation in the other gamete, so that normal gene dosage is maintained. All clitellate annelids are hermaphroditic, but self-fertilization is rare. To our knowledge, three species of Helobdella are the only clitellates for which self-fertilization has been documented. We have recently speculated that this combination of developmental cell lineage and reproductive history may account for the dramatic loss of macrosynteny (the conserved linkage of orthologous genes) between Helobdella and other species (for example, as described above for the Hox complex genes). Testing this explanation for the observed genome rearrangements would require denser sampling of genome architecture and reproductive strategies among leeches and related annelids.

\section{Conclusions: prospects for future studies}

The material presented above is intended to give a quick overview of Helobdella development as we know it today, and to outline some emerging questions for those who might be tempted to investigate further. Leeches such as Helobdella and other annelids provide interesting material for studying diverse topics, such as cell fate determination, developmental dynamics of the transcriptome, evolutionary dynamics of the genome, lineage-driven segmentation, stem cell mechanisms, and regeneration.

A PubMed search on the keyword Drosophila yields more than 85,000 entries and searching on Caenorhabditis yields more than $21,000-$-yet no one would claim that our understanding of these exhaustively studied embryos is anywhere near complete. By contrast, searching on Helobdella yields 134 entries--clearly we have only begun to outline the main features of development in this embryo. Given the fact that annelids, molluscs and other lophotrochozoans have been evolving independently of ecdysozoans and deuterostomes for the better part of one billion years, it seems reasonable to expect that they have explored different regions of the ill-defined, highly-dimensional space of possible developmental mechanisms. We anticipate that the apparent dynamic activation of MAPK, Notch and Wnt signaling pathways in the 2-cell stage, novel deployment of the BMP signaling pathway in DV patterning and a segmentation process driven by stereotyped cell lineages rather than imposition of boundaries in Helobdella are but the first of many interesting observations to be made in this system.

\section{Acknowledgements}

The authors thank members of their laboratories for helpful discussion and Dr. Elizabeth Heath-Heckman for valuable editorial comments. Research from DAW's laboratory reported here has been supported by grants from the National Science Foundation and the National Institutes of Health. DHK's research is funded by grants from Ministry of Science and Technology (Taiwan) and National Taiwan University.

\section{References}

AMIELAR, HENRY J Q and SEAVER E C (2013). An organizing activity is required for head patterning and cell fate specification in the polychaete annelid Capitella teleta: new insights into cell-cell signaling in Lophotrochozoa. Dev Biol. 379: 107-122.

ARAI A, NAKAMOTO A, SHIMIZU T (2001). Specification of ectodermal teloblast 
lineages in embryos of the oligochaete annelid Tubifex: involvement of novel cell-cell interactions. Development 128: 1211-1219.

ASTROW S, HOLTON B, WEISBLAT D A (1987). Centrifugation redistributes factors determining cleavage patterns in leech embryos. Dev Biol 120: 270-283.

ASTROW SH, HOLTONB and WEISBLAT DA(1989). Teloplasm formation in a leech, Helobdella triserialis, is a microtubule-dependent process. Dev Biol 135:306-319.

BELY A E, NYBERG K G (2010) Evolution of animal regeneration: re-emergence of a field. Trends Ecol Evol 25:161-170.

BELY A E (2006). Distribution of segment regeneration ability in the Annelida. Integr Comp Biol 46:508-518

BISSEN S T, WEISBLAT D A (1987). Early differences between alternate $\mathrm{n}$ blast cells in leech embryo. J Neurobiol 18: 251-269.

BISSEN S T, WEISBLAT D A (1989). The durations and compositions of cell cycles in embryos of the leech, Helobdella triserialis. Development 106: 105-118.

BRAUN J, STENT G S (1989a). Axon outgrowth along segmental nerves in the leech. I. Identification of candidate guidance cells. Dev Biol 132: 471-485.

BRAUN J, STENT G S (1989b). Axon outgrowth along segmental nerves in the leech. II. Identification of actual guidance cells. Dev Biol 132: 486-501.

CHEN C Y, SHYU A B (1995). AU-rich elements: characterization and importance in mRNA degradation. Trends Biochem Sci 20: 465-470.

CHO S J, VALLÈS Y, GIANI V C JR, SEAVER E C, WEISBLAT D A (2010). Evolutionary dynamics of the Wnt gene family: a lophotrochozoan perspective. $\mathrm{Mol} \mathrm{BiO}$ Evol 27: 1645-1658.

CHO S J, VALLĖS Y, WEISBLAT D A (2014). Differential expression of conserved germ line markers and delayed segregation of male and female primordial germ cells in a hermaphrodite, the leech Helobdella. Mol Biol Evol 31: 341-354.

DE ROBERTIS E M, SASAI Y (1996). A common plan for dorsoventral patterning in Bilateria. Nature 380: 37-40.

DESJEUX I, PRICE D J (1999). The production and elimination of supernumerary blast cells in the leech embryo. Dev Genes Evol 209: 284-293.

DOHLE W (1999). The ancestral cleavage pattern of the clitellates and its phylogenetic deviations. Hydrobiologia 402: 267-283.

DUBOULE D (2007). The rise and fall of Hox gene clusters. Development 134: 2549-2560

FERNANDEZ J, STENT G S (1980). Embryonic development of the glossiphoniid leech Theromyzon rude: structure and development of the germinal band. Dev Biol 78: 407-434.

FREEMAN G, LUNDELIUS J W (1992). Evolutionary implications of the mode of D quadrant specification in coelomates with spiral cleavage. J Evol Biol 5: 205-247.

GIRIBET G (2008). Assembling the lophotrochozoan (=spiralian) tree of life. Philos Trans $R$ Soc Lond B Biol Sci 363:1513-1522.

GLINE SE, NAKAMOTO A, CHO S J, CHI C, WEISBLAT D A(2011). Lineage analysis of micromere $4 \mathrm{~d}$, a super-phylotypic cell for Lophotrochozoa, in the leech Helobdella and the sludgeworm Tubifex. Dev Biol 353: 120-133.

GONSALVES F C, WEISBLAT D A (2007). MAPK regulation of maternal and zygotic Notch transcript stability in early development. Proc NatlAcad SciUSA 104:531-536.

GOTO A, KITAMURAK, ARAI A, SHIMIZU T (1999a). Cell fate analysis of teloblasts in the Tubifex embryo by intracellular injection of HRP. Dev Growth Diff 41: 703-713.

GOTOA, KITAMURAK, SHIMIZU T (1999b). Cell lineage analysis of pattern formation in the Tubifexembryo. I. Segmentation in the mesoderm. Int J Dev Biol43:317-327.

HENRY J J, PERRY K J (2008). MAPK activation and the specification of the D quadrant in the gastropod mollusc, Crepidula fornicata. Dev Biol313: 181-195.

HO R K, WEISBLAT D A (1987). A provisional epithelium in leech embryo: cellular origins and influence on a developmental equivalence group. Dev Biol120:520-534

HOLTON B, ASTROW S H, WEISBLAT D A (1989). Animal and vegetal teloplasms mix in the early embryo of the leech, Helobdella triserialis. Dev Biol 131: 182-188.

HOLTON B, WEDEEN C J, ASTROW S H, WEISBLAT D A (1994). Localization of polyadenylated RNAs during teloplasm formation and cleavage in leech embryos. Roux's Arch Dev Biol 204: 46-53.

HUANG F Z, BELY A E, WEISBLAT D A (2001). Stochastic WNT signaling between nonequivalent cells regulates adhesion but not fate in the two-cell leech embryo. Curr Biol 11: 1-7.

HUANG FZ, KANG D, RAMIREZ-WEBERFA, BISSENST, WEISBLATDA(2002). Mi- cromere lineage in the glossiphoniid leech Helobdella. Development 129:719-732.

HUANG F Z, WEISBLAT D A (1996). Cell fate determination in an annelid equivalence group. Development 122: 1839-1847.

ISAKSEN D E, LIU N J L, WEISBLAT D A (1999). Inductive regulation of cell fusion in leech. Development 126: 3381-3390.

ISHII R, SHIMIZU T (1995). Unequal first cleavage in the Tubifex egg: involvement of a monastral mitotic apparatus. Dev Growth Diff 37: 687-701.

ISHII R, SHIMIZU T (1997). Equalization of unequal first cleavage in the Tubifex egg by introduction of an additional centrosome: implications for the absence of cortical mechanisms for mitotic spindle asymmetry. Dev Biol 189: 49-56.

JULIANO C E, SWARTZ S Z, WESSEL G M (2010). A conserved germline multipotency program. Development 137: 4113-4126.

KANG D, PILON M, WEISBLAT D A (2002). Maternal and zygotic expression of a nanos-class gene in the leech Helobdella robusta: primordial germ cells arise from segmental mesoderm. Dev Biol 245: 28-41.

KOOP D, RICHARDS G S, WANNINGER A, GUNTER H M, DEGNAN B M (2007) The role of MAPK signaling in patterning and establishing axial symmetry in the gastropod Haliotis asinina. Dev Biol 311: 200-212.

KOURAKIS M J, MASTER V A, LOKHORST D K, NARDELLI-HAEFLIGER D, WEDEEN C J, MARTINDALE M Q, SHANKLAND M (1997). Conserved anterio boundaries of Hox gene expression in the central nervous system of the leech Helobdella. Dev Biol 190: 284-300.

KRAMER A P, WEISBLAT D A (1985). Developmental neural kinship groups in the leech. J Neurosci 5: 388-407.

KUO D-H, SHANKLAND M (2004a). A distinct patterning mechanism of the $\mathrm{O}$ and $P$ cell fates in the development of the rostral segments of the leech Helobdella robusta: implication for the evolutionary dissociation of developmental pathway and morphological outcome. Development 131: 105-115.

KUO D-H, SHANKLAND M (2004b). Evolutionary diversification of specification mechanisms within the O/P equivalence group of the leech genus Helobdella. Development 131: 5859-5869.

KUO D-H, WEISBLAT D A (2011). A new molecular logic for BMP-mediated dorsoventral patterning in the leech Helobdella. Curr Biol 21: 1282-1288.

KUTSCHERA U, LANGGUTH H, KUO D-H, WEISBLAT D A, SHANKLAND M (2013) Description of a new leech species from North America, Helobdella austinensis n. sp. (Hirudinea: Glossiphoniidae), with observations on its feeding behaviour. Zoosyst Evol 89: 239-246.

LAMBERT J D, NAGY L M (2001). MAPK signaling by the D quadrant embryonic organizer of the mollusc Ilyanassa obsoleta. Development 128: 45-56.

LAMBERT J D, NAGY L M (2003). The MAPK cascade in equally cleaving spiralian embryos. Dev Biol 263: 231-241.

LANS D, WEDEEN C J, WEISBLAT D A (1993). Cell lineage analysis of the expression of an engrailed homolog in leech embryos. Development 117: 857-871.

LASA M, MAHTANI K R, FINCH A, BREWER G, SAKLATVALA J, CLARKAR (2000). Regulation of cyclooxygenase 2 mRNA stability by the mitogen-activated protein kinase p38 signaling cascade. Mol Cell Biol 20: 4265-4274.

LIU N-J L, ISAKSEN D E, SMITH C M, WEISBLAT D A (1998). Movements and stepwise fusion of endodermal precursor cells in leech. Dev Genes Evol208: 117-127.

LYONS D C, WEISBLAT D A (2009). D quadrant specification in the leech Helobdella: actomyosin contractility controls the unequal cleavage of the CD blastomere. Dev Biol 334: 46-58.

MCHUGH D (2000). Molecular phylogeny of the Annelida. Can J Zool 78: 1873-1884

MULLER K J, NICHOLLS J G and STENT G S (1981). Neurobiology of the Leech Cold Spring Harbor, NY: Cold Spring Harbor Laboratory Press.

NAKAMOTO A, ARAI A, SHIMIZU T (2000). Cell lineage analysis of pattern formation in the Tubifexembryo. II. Segmentation in the ectoderm. Int J Dev Biol44:797-805.

NARDELLI-HAEFLIGER D, BRUCE A E, SHANKLAND M (1994). An axial domain of $\mathrm{HOM} / \mathrm{Hox}$ gene expression is formed by morphogenetic alignment of independently specified cell lineages in the leech Helobdella. Development 120: 1839-1849.

NARDELLI-HAEFLIGER D, SHANKLAND M (1992). Lox2, a putative leech segment identity gene, is expressed in the same segmental domain in different stem cell lineages. Development 116: 697-710.

NARDELLI-HAEFLIGER D, SHANKLAND M (1993). Lox10, a member of the NK-2 homeobox gene class, is expressed in a segmental pattern in the endoderm and in 
the cephalic nervous system of the leech Helobdella. Development 118: 877-892.

NELSONBH, WEISBLATDA(1992). Cytoplasmic and cortical determinants interact to specify ectoderm and mesoderm in the leech embryo. Development 115: 103-115.

OHKAWARA B, IEMURA S, TEN DIJKE P, UENO N (2002). Action range of BMP is defined by its N-terminal basic amino acid core. Curr Biol 12: 205-209.

OLIVARES G H, CARRASCO H, AROCA F, CARVALLO L, SEGOVIA F and LARRA $\mathrm{N} \mathrm{J} \mathrm{(2009).} \mathrm{Syndecan-1} \mathrm{regulates} \mathrm{BMP} \mathrm{signaling} \mathrm{and} \mathrm{dorso-ventral} \mathrm{patterning}$ of the ectoderm during early Xenopus development. Dev Biol 329: 338-349.

PILON M, WEISBLAT D A (1997). A nanos homolog in leech. Development 124: 1771-1780.

RAMIREZ F, RIFKIN D B (2009). Extracellular microfibrils: contextual platforms for TGF $\beta$ and BMP signaling. Curr Opin Cell Biol 21: 616-622.

REN X, WEISBLAT D A (2006). Asymmetrization of first cleavage by transient disassembly of one spindle pole aster in the leech Helobdella robusta. Dev Biol 292: 103-115.

SANDIG M, DOHLE W (1988). The cleavage pattern in the leech Theromyzon tessulatum. J Morphol 196: 217-252.

SAWYER R (1986). Leech Biology and Behaviour. Clarendon Press, Oxford.

SCHMERER M, SAVAGE R M, SHANKLAND M (2009). Pax $\beta$ : a novel family of lophotrochozoan Pax genes. Evol Dev 11: 689-696.

SCHMERER M W, NULL R W, SHANKLAND M (2013). Developmental transition to bilaterally symmetric cell divisions is regulated by Pax-mediated transcription in embryos of the leech Helobdella austinensis. Dev Biol 382: 149-159.

SHAIN D H, RAMIREZ-WEBER F-A, HSU J, WEISBLAT D A (1998). Gangliogenesis in leech: morphogenetic processes leading to segmentation in the central nervous system. Dev Genes Evol 208: 28-36.

SHANKLAND M (1984). Positional determination of supernumerary blast cell death in the leech embryo. Nature 307: 541-543.

SHANKLANDM (1987). Cell lineage in leechembryogenesis. Trends Genet 3:314-319.

SHANKLAND M and SAVAGE R M (1997). Annelids, the segmented worms. In Embryology: Constructing the Organism, (ed. GILBERT, S. F. and RAUNIO, A. M.). Sinauer, Sunderland, MA, pp. 219-235.

SHANKLAND M (1999). Anteroposterior pattern formation in the leech embryo. In Cell Lineage and Fate Determination. Academic Press, San Diego, CA, pp. 207-224.

SHIMIZU T (1982a). Development in the freshwater oligochaete Tubifex. In Developmental Biology of Freshwater Invertebrates (F.W. Harrison and R.R. Cowden, Eds.) A.R. Liss, Inc., New York. pp.283-316.

SHIMIZU T (1982b). Ooplasmic segregation in the Tubifex egg: mode of pole plasm accumulation and possible involvement of microfilaments. Roux's Arch Dev Biol 191: $246-256$

SIDDALLME, APAKUPAKULK, BURRESONEM, COATESKA, ERSEUSC, GELDER S R, KALLERSJO M, TRAPIDO-ROSENTHAL H (2001). Validating Livanow: molecular data agree that leeches, branchiobdellidans, and Acanthobdella peledina form a monophyletic group of oligochaetes. Mol Phylogenet Evol 21: 346-351.

SIMAKOV O, MARLETAZ F, CHO S J, EDSINGER-GONZALES E, HAVLAK P, HELLSTEN U, KUO D-H, LARSSON T, LV J, ARENDT D et al., (2013). Insights into bilaterian evolution from three spiralian genomes. Nature 493: 526-531.

SMITH C M, LANS D, WEISBLAT D A (1996). Cellular mechanisms of epiboly in leech embryos. Development 122: 1885-1894.

SMITH C M, WEISBLAT D A (1994). Micromere fate maps in leech embryos: lineagespecific differences in rates of cell proliferation. Development 120: 3427-3438.

STOREY K G (1989). Cell lineage and pattern formation in the earthworm embryo. Development 107: 519-531.
STRUCK T H, PAUL C, HILL N, HARTMANN S, HOSEL C, KUBE M, LIEB B, MEYER A, TIEDEMANN R, PURSCHKE G et al., (2011). Phylogenomic analyses unravel annelid evolution. Nature 471: 95-98

STRUCK T (2014). Platyzoan paraphyly based on phylogenomic data supports a non-coelomate ancestry of Spiralia. Mol Biol Evol doi: 10.1093/molbev/msu143

TAKADA T, KATAGIRI T, IFUKU M, MORIMURA N, KOBAYASHI M, HASEGAWA K OGAMO A, KAMIJO R (2003). Sulfated polysaccharides enhance the biological activities of bone morphogenetic proteins. J Biol Chem 278: 43229-43235.

TAKAHASHI H, SHIMIZU T (1997). Role of intercellular contacts in generating an asymmetric mitotic apparatus in the Tubifex embryo. Dev Growth Diff39: 351-362.

TAN G N, GOVEDICH F R, BURD M (2004). Social group size, potential sperm competition and reproductive investment in a hermaphroditic leech, Helobdella papillornata (Euhirudinea: Glossiphoniidae). J Evol Biol 17: 574-580.

TORRENCE S A, STUART D K (1986). Gangliogenesis in leech embryos: migration of neural precursor cells. J Neurosci 6: 2736-2746.

WANG X, HARRIS R E, BAYSTON L J, ASHE H L (2008). Type IV collagens regulate BMP signalling in Drosophila. Nature 455: 72-77

WEDEEN C J, PRICE D J and WEISBLAT D A (1990). Analysis of the life cycle, genome and homeo box genes of the leech, Helobdella triserialis. In The Cellular and Molecular Biology of Pattern Formation, (ed. STOCUM, D. L. and KARR, T. L.). Oxford University Press, Oxford, pp.145-167.

WEDEEN C J, SHANKLAND M (1997). Mesoderm is required for the formation of a segmented endodermal cell layer in the leech Helobdella. Dev Biol 191: 202-214.

WEISBLAT D A, BLAIR S S (1984). Developmental indeterminacy in embryos of the leech Helobdella triserialis. Dev Biol 101: 326-335.

WEISBLAT D A and KUO D-H (2009). Helobdella (Leech): a model for developmental studies. In Emerging Model Organisms: a Laboratory Manual. Cold Spring Harbor Laboratory Press, Cold Spring Harbor, NY, pp. 245-267.

WEISBLAT D A, SAWYER R T, STENT G S (1978). Cell lineage analysis by intracellular injection of a tracer enzyme. Science 202: 1295-1298.

WEISBLAT D A, HARPER G, STENT G S, SAWYER R T (1980). Embryonic cell lineages in the nervous system of the glossiphoniid leech Helobdella triserialis. Dev Biol 76: 58-78.

WEISBLAT D A, KIM S Y, STENT G S (1984). Embryonic origins of cells in the leech Helobdella triserialis. Dev Biol 104: 65-85.

WEISBLAT D A, SHANKLAND M (1985). Cell lineage and segmentation in the leech Phil Trans $R$ Soc Lond B 312: 39-56.

WEISBLAT D A, ZACKSON S L, BLAIR S S, YOUNG J D (1980). Cell lineage analysis by intracellular injection of fluorescent tracers. Science 209: 1538-1541.

WHITMAN C O (1878). The embryology of Clepsine. Q J Microsc Sci 18: 213-315.

ZACKSON S L (1982). Cell clones and segmentation in leech development. Cell 31: $761-770$

ZACKSON S L (1984). Cell lineage, cell-cell interaction, and segment formation in the ectoderm of a glossiphoniid leech embryo. Dev Biol 104: 143-160.

ZHANG S O, KUO D-H, WEISBLAT D A (2009). Grandparental stem cells in leech segmentation: differences in CDC42 expression are correlated with an alternating pattern of blast cell fates. Dev Biol 336: 112-121.

ZHANG S O, WEISBLAT D A (2005). Applications of mRNA injections for analyzing cell lineage and asymmetric cell divisions during segmentation in the leech Helobdella robusta. Development 132: 2103-2113.

ZHU Y, OGANESIAN A, KEENE D R, SANDELL L J (1999). Type IIA procollagen containing the cysteine-rich amino propeptide is deposited in the extracellular matrix of prechondrogenic tissue and binds to TGF- $\beta 1$ and BMP-2. J Cell Biol 144: 1069-1080. 


\section{Further Related Reading, published previously in the Int. J. Dev. Biol.}

Planarian embryology in the era of comparative developmental biology José M. Martín-Durán, Francisco Monjo and Rafael Romero

Int. J. Dev. Biol. (2012) 56: 39-48

Function and specificity of Hox genes

David Foronda, Luis F. de Navas, Daniel L. Garaulet and Ernesto Sánchez-Herrero Int. J. Dev. Biol. (2009) 53: 1409-1419

\section{Segmentation, metamerism and the Cambrian explosion} Juan Pablo Couso

Int. J. Dev. Biol. (2009) 53: 1305-1316

The first bilaterian organisms: simple or complex? New molecular evidence J Baguna, I Ruiz-Trillo, J Paps, M Loukota, C Ribera, U Jondelius, M Riutort Int. J. Dev. Biol. (2001) 45: S133-S134

5 yr ISI Impact Factor $(2011)=2.959$
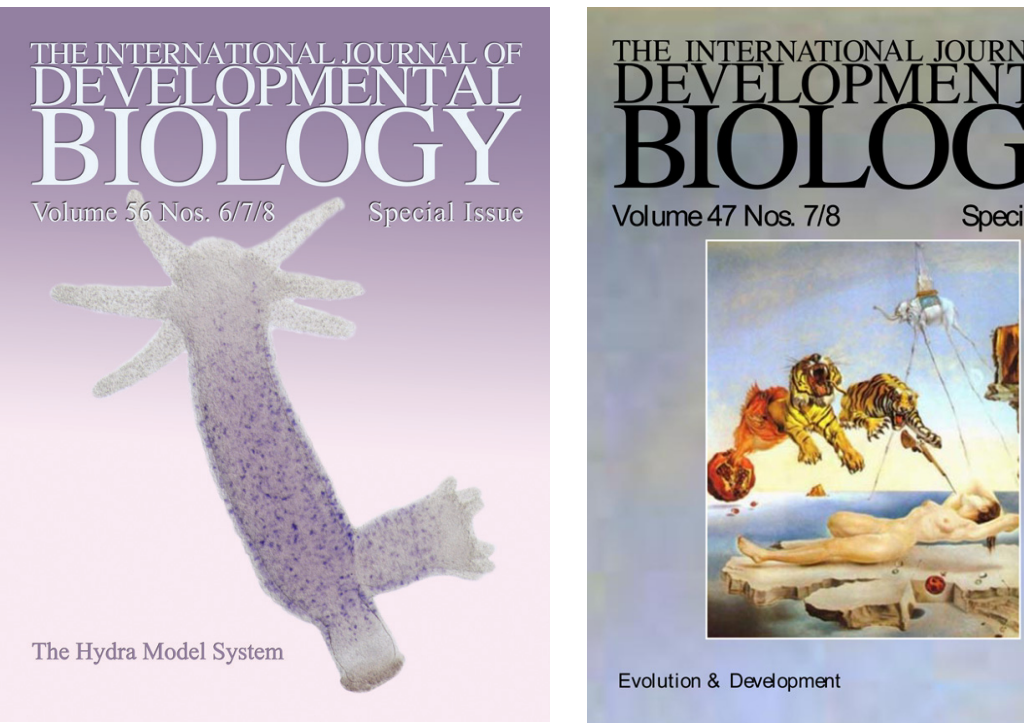

Evolution \& Development
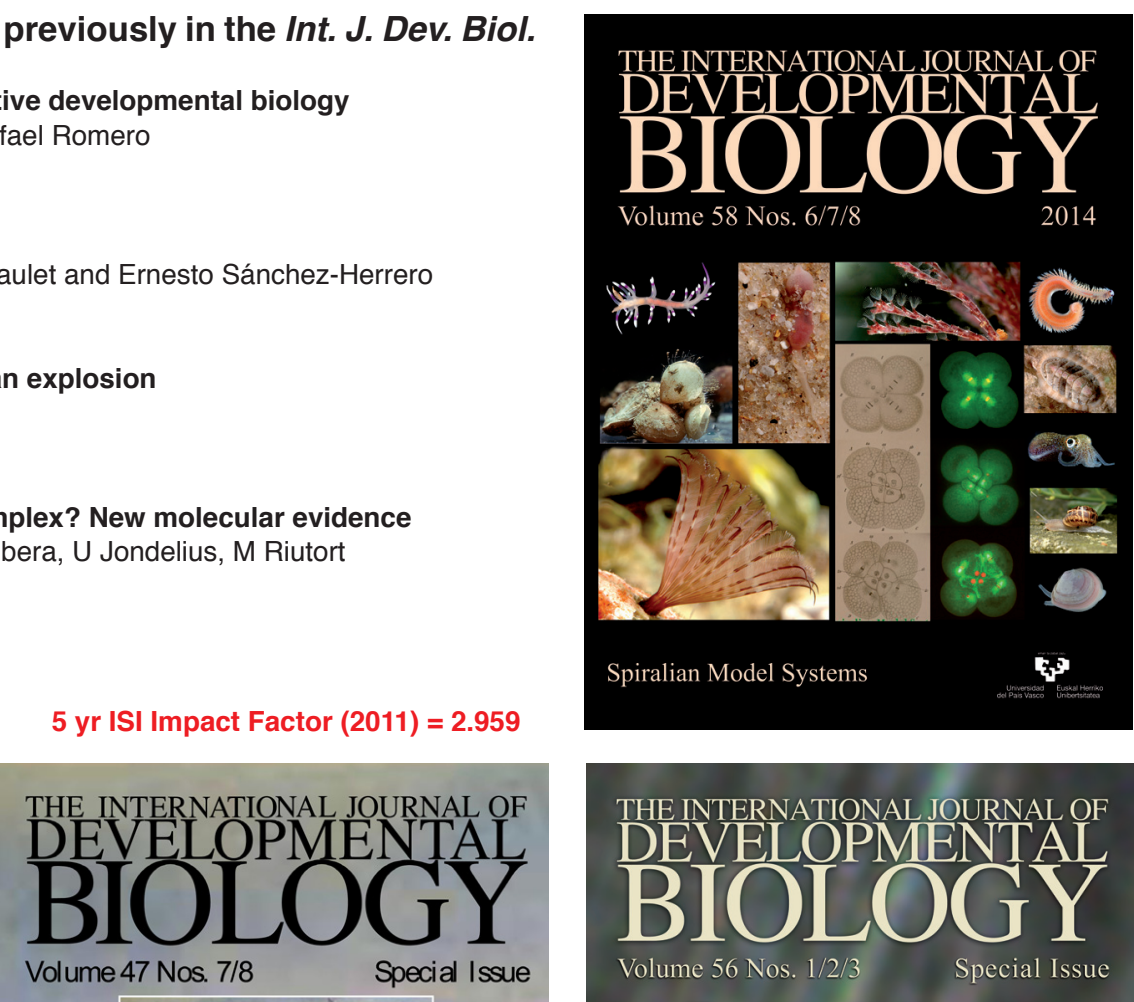

Volume 56 Nos. $1 / 2 / 3$

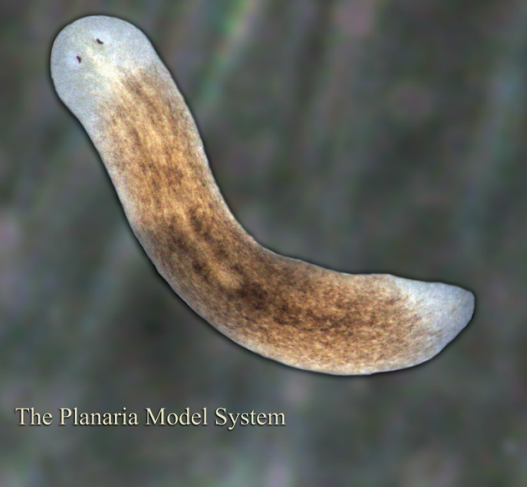

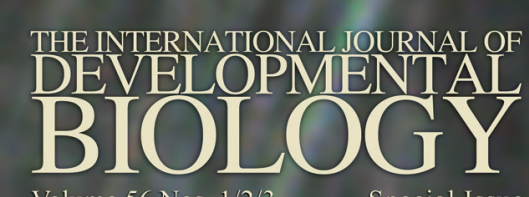

